Article

\title{
Physiological Responses to the Foliar Application of Synthetic Resistance Elicitors in Cape Gooseberry Seedlings Infected with Fusarium oxysporum f. sp. physali
}

\author{
Cristhian C. Chávez-Arias $\mathbb{D}$, Sandra Gómez-Caro and Hermann Restrepo-Díaz *(iD) \\ Departamento de Agronomía, Facultad de Ciencias Agrarias, Universidad Nacional de Colombia, \\ Carrera 30 No. 45-03, Bogotá 111321, Colombia; ccchaveza@unal.edu.co (C.C.C.-A.); \\ sgomezc@unal.edu.co (S.G.-C.) \\ * Correspondence: hrestrepod@unal.edu.co; Tel.: +57-1-316-5000 (ext. 19018)
}

Received: 2 December 2019; Accepted: 26 January 2020; Published: 1 February 2020

\begin{abstract}
Vascular wilt caused by Fusarium oxysporum is the most limiting disease that affects cape gooseberry (Physalis peruviana L.) crops in Colombia. The use of synthetic elicitors for vascular wilt management is still scarce in Andean fruit species. The objective of the present study was to evaluate the effect and number of foliar applications of synthetic elicitors such as jasmonic acid (JA), salicylic acid (SA), brassinosteroids (BR), or a commercial resistance elicitor based on botanical extracts (BE) on disease progress and their effect on the physiology of cape gooseberry plants inoculated with F. oxysporum f. sp. physali. Groups of ten plants were separately sprayed once, twice, or three times with a foliar synthetic elicitor, respectively. Elicitor applications were performed at the following concentrations: JA $\left(10 \mathrm{~mL} \mathrm{~L}^{-1}\right)$, SA $\left(100 \mathrm{mg} \mathrm{L}^{-1}\right), \mathrm{BR}\left(1 \mathrm{~mL} \mathrm{~L}^{-1}\right)$ and $\mathrm{BE}(2.5 \mathrm{~mL}$ of commercial product $\left(\right.$ Loker $\left.^{\circledR}\right) \mathrm{L}^{-1}$ ). The results showed that three foliar $\mathrm{BR}, \mathrm{SA}$, or $\mathrm{BE}$ applications reduced the area under the disease progress, severity index, and vascular browning in comparison to inoculated plants without any elicitor spray. Three BR, SA, or BE sprays also favored stomatal conductance, water potential, growth (total dry weight and leaf area) and fluorescence parameters of chlorophyll compared with inoculated and untreated plants with no elicitor sprays. Three foliar sprays of SA, BR, or BE enhanced photosynthetic pigments (leaf total chlorophyll and carotenoid content) and proline synthesis and decreased oxidative stress in Foph-inoculated plants. In addition, the effectiveness of three foliar BR, SA, or BE sprays was corroborated by three-dimensional plot and biplot analysis, in which it can evidence that stomatal conductance, proline synthesis, and efficacy percentage were accurate parameters to predict Foph management. On the hand, JA showed the lowest level of amelioration of the negative effects of Foph inoculation. In conclusion, the use of the synthetic elicitors $\mathrm{BR}, \mathrm{SA}$, or BE can be considered as a tool complementary for the commercial management of vascular wilt in areas where this disease is a limiting factor.
\end{abstract}

Keywords: foliar sprays; lipid peroxidation; plant defense mechanisms; rapid light-response curves; vascular wilt

\section{Introduction}

Cape gooseberry (Physalis peruviana L.) is a species that belongs to the Solanaceae family, native to the Peruvian Andean zones [1]. This species benefits human health due to its high vitamin, mineral (phosphorus and iron), and fiber contents, as well as its levels of antioxidant compounds (ascorbic acid and provitamin A) [2-5]. In Colombia, cape gooseberry crops occupied an area of 1023 ha with a 
production of 15,112 $\mathrm{t}$ in 2017 [6]. This species is also the second most exported fruit in the country followed by plantain and banana [1].

A reduction of cape gooseberry productivity has been registered (from $18 \mathrm{t} / \mathrm{ha}$ in 2009 to $15 \mathrm{t} / \mathrm{ha}$ in 2014) in the last years in Colombia [6,7]. One of the main causes of this reduction is vascular wilt, caused by the soil pathogen Fusarium oxysporum f. sp. physali (Foph) [8,9], which causes turgor loss in young leaves and stems, chlorosis in old leaves, branch drying and plant growth inhibition [8].

Chlamydospores production guarantees Foph long-term survival in the soil, making disease management difficult [7]. Vascular wilt control has been focused exclusively on the use of chemical fungicides, generating resistance by the pathogen, environmental contamination and low crop profitability $[8,10]$. Also, the implementation of cultural practices such as elimination of infected plants or soil solarization is scarce by growers [8]. This lack of control strategies has generated, in some cases, total crop death [9]. For this reason, the development of alternative methods for the management of soil pathogens has been of growing interest in recent years [11].

One of the strategies to mitigate the negative impact of plant pathogens on growth and crop yield is the application of synthetic elicitors which enhances plant defense mechanisms [12,13]. Elicitors are stable molecules that signal plant immune defense responses and improve plant physiological status under biotic stresses [14,15]. Different types of synthetic elicitors such as inorganic compounds, lipids, glycopeptides, and glycoproteins have been characterized and studied $[13,16]$. The most commonly studied synthetic elicitors against biotic stress are salicylic acid (SA) $[17,18]$, jasmonic acid (JA) $[19,20]$ and brassinosteroids (BR) [21,22].

SA plays a critical role in plant defense to biotic and abiotic stress [23,24]. Systemic acquired resistance (SAR) is one of the most representative forms of plant defense mechanisms induced by SA [17]. Foliar SA application has been used to promote SAR in pathogen-infected plants [20,25]. Also, exogenous SA application decreased leaf lesions caused by Glomerella cingulata and increased the total antioxidant capacity (catalase, superoxide dismutase and peroxidase) in apple (Malus domestica Borkh.) plants [26].

BR are involved in a large number of processes in plants, which mainly include seed germination, stem elongation, cell division and expansion, xylem differentiation and apical dominance [21]. Likewise, BR enhance metabolite synthesis ( $\gamma$-Aminobutyric acid, D-galactose, and proline) and antioxidant machinery (peroxidase, catalase and ascorbate peroxidase) to protect plant cells from pathogen infestation [27-29]. Furio et al. [30] observed that foliar BR application induced a defense response in strawberry (Fragaria $x$ ananassaa) plants infected with Colletotrichum acutatum by increasing lignin and callose deposits. Similarly, Canales et al. [31] showed that BR can be a useful tool for the management of Huanglongbing (HLB) in citrus trees (Citrus aurantifolia (Christm) Swingle).

JA is also a plant hormone that can promote plant tolerance against diseases by the induced systemic resistance (ISR) mechanism [32]. ISR promotes physiological processes that allow plants to react more efficiently to biotic stress [33,34]. Ávila et al. [35] found that foliar JA application prior to Fusarium oxysporum f.sp. quitoense inoculation protected lulo (Solanum quitoense L.) plants and generated the activation of the signaling pathway to induce resistance.

Commercial botanical extracts (BE) have been used to improve the plant's immune system as a management strategy to reduce synthetic fungicides use [36,37]. The benefit of the application of these compounds is that they are highly biodegradable and toxic to several arthropod pests and pathogens $[15,38,39]$. Phenylpropanoids are aromatic hydrocarbons that constitute different botanical extracts and are involved in various disease resistance responses through secondary metabolites synthesis such as phenolics, flavonoids, lignin and anthocyanins [40]. In this sense, commercial products based on different botanical extracts are also rich in polysaccharides, and amino acids that can act as defense inducers in plants [41,42].

The physiological and biochemical plant responses are important traits to characterize possible defense mechanisms to biotic stress conditions associated with plant pathogens [43,44]. Physiological parameters such as leaf gas exchange properties, leaf water potential, and plant canopy growth and 
temperature have been used to characterize genotypes tolerance to pathogen infection [45]. Also, proline content has been correlated with plant defense against diseases [46]. In addition, malondialdehyde (MDA) production has also been used as a biochemical parameter to characterize plant responses to pathogens attack [44].

SA, JA, and BR are molecules that are involved in several plant physiological processes [47-49]. For example, SA is involved in leaf gas exchange (photosynthesis rate, stomatal conductance), water relations, and modulates plant response to environmental stress [50]. In turn, JA promotes several mechanisms to stress acclimation such as plant growth, morphological changes and proline accumulation [51,52]. Finally, BR can regulate stomatal closure and leaf senescence, and favor plant resistance to stress agents $[53,54]$.

Studies on the use of synthetic elicitors have been mainly focused on the control of diseases through the induction of resistance mechanisms [17,19,21]. However, the available literature about elicitors use in disease management of Andean fruit trees such as cape gooseberry is still scarce. For this reason, the objective of the present study was to evaluate the effect and number of foliar applications of four different synthetic elicitors (salicylic acid (SA), brassinosteroids (BR), jasmonic acid (JA) and a commercial product (Loker ${ }^{\circledR}$, Bologna, Italy) based on botanical extracts (BE)) on stomatal conductance, leaf water potential, chlorophyll fluorescence parameters, plant growth and biochemical responses of cape gooseberry seedlings infected with Foph.

\section{Results}

\subsection{Vascular Wilt Severity Expressed as AUDPC, Disease Index, and Vascular Browning}

The area under the disease progress curve (AUDPC), the disease index and vascular browning are presented in Figure 1. Foph-inoculated plants from all treatments showed common symptoms of vascular wilt, and Foph presence was confirmed by isolates from affected material in PDA (data not shown). Also, this technique confirmed the pathogen's absence in plants without inoculation and foliar elicitors applications (control plants).

Significant differences $(p=0.021)$ were observed in the interaction between factors on AUDPC, disease index and vascular browning. In general, a negative linear trend was observed in these variables (AUDPC, severity index and vascular browning) when number of foliar elicitor applications increased (Figure 1A-C). Three foliar BR or SA applications showed a lower vascular wilt AUDPC (36.8 and 40.8) and severity index (3.25 and 3.5) compared to BE (47 for AUDPC and 4 for the disease index), respectively (Figure 1A, B). On the other hand, plants treated with JA did not show any statistical differences in these two parameters compared with untreated inoculated plants. Regarding vascular browning percentage, a negative linear trend was observed between this variable and the foliar sprays number in all elicitors. Foph-inoculated plants and sprayed with BR (2.25), SA (2.5) and BE (2.5) showed lower vascular browning (Figure 1C).

Finally, the efficacy percentage showed that an increase in the number of foliar sprays, mainly BR, $\mathrm{SA}$, or BE, was able to reduce symptoms in Foph-infected plants (Figure 2). The previous tendency is confirmed by Figure 3 in which the image shows that Foph-inoculated plants without any foliar elicitor spray had the greater vascular browning in comparison with the other treatments. 


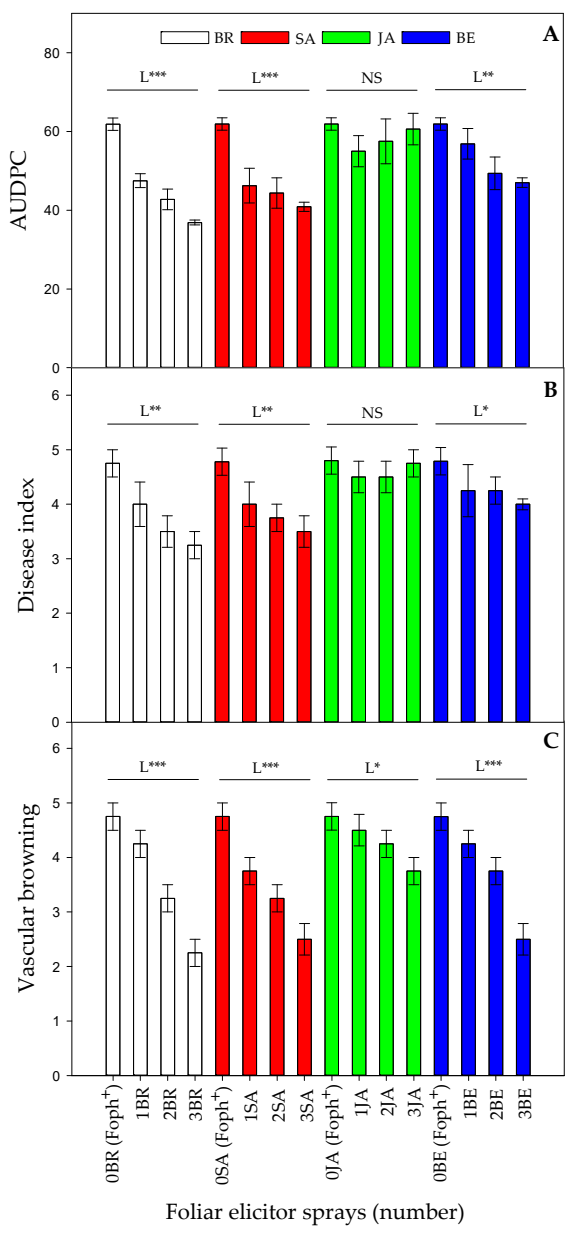

Figure 1. Effect of the interaction between synthetic elicitors (Salicylic acid (SA), jasmonic acid (JA), Brassinosteroids (BR), or botanical extracts (BE)) and the sprays number (0, 1, 2 and 3 applications) on area under the disease progress curve (AUDPC) (A), vascular wilt index (B) and vascular browning (C) in Fusarium oxysporum f. sp. physali (Foph ${ }^{+}$) infected cape gooseberry (Physalis peruviana L.) plants at 50 DAI. Each point represents the average of ten plants $(n=10)$. NS, not significant at $\alpha=0.05 . *{ }^{* *}$ and *** significant at $\mathrm{P} \leq 0.05,0.01$ and 0.001 , respectively. $\mathrm{L}=$ linear.

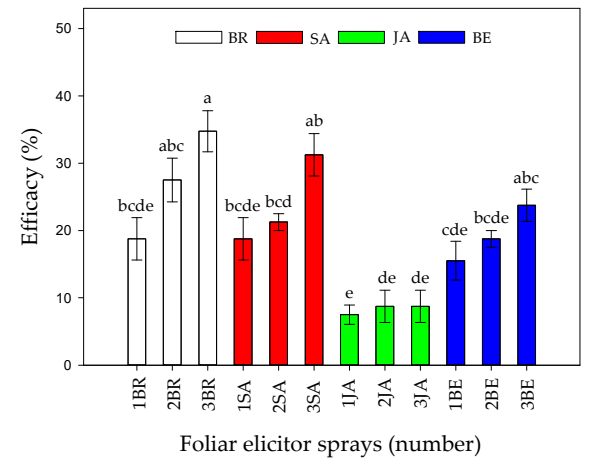

Figure 2. Effect of the interaction between synthetic elicitors (Salicylic acid (SA), jasmonic acid (JA), Brassinosteroids (BR), or botanical extracts (BE)) and the sprays number $(0,1,2$ and 3 applications) on control efficacy in Fusarium oxysporum f. sp. physali infected cape gooseberry (Physalis peruviana L.) plants at 50 DAI. Data represent the average of ten plants \pm SE per treatment $(n=10)$. Bars followed by different letters indicate statistically significant differences according to the Tukey test $(p \leq 0.05)$. 


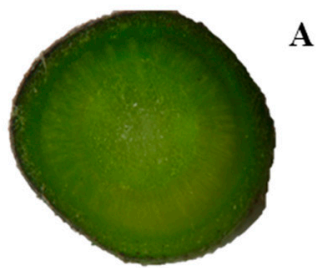

Control plants

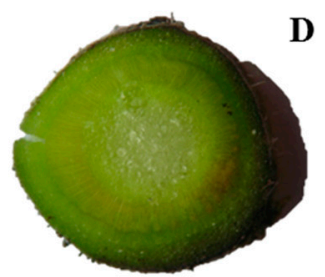

Foph inoculated after three foliar SA sprays

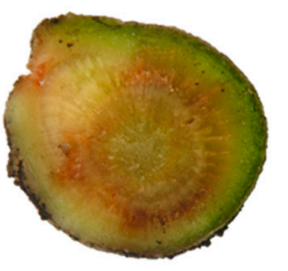

Foph inoculated

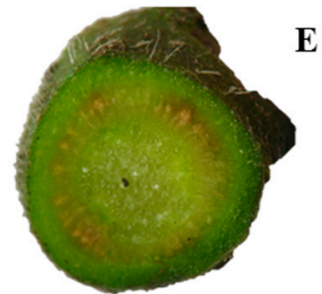

Foph inoculated after three foliar JA sprays

B

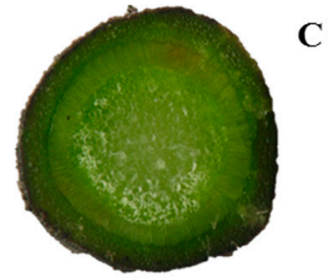

Foph inoculated after three foliar BR sprays

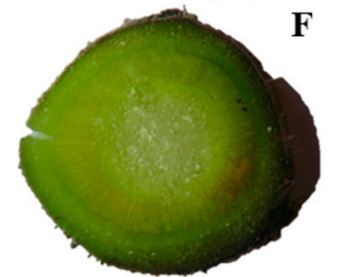

Foph inoculated after three foliar BE sprays

Figure 3. Vascular browning of cape gooseberry plants with different Fusarium oxysporum f. sp. physali $\left(\mathrm{Foph}^{+}\right.$) inoculation and synthetic elicitors sprays. Control plants (non-inoculated plants and without any synthetic elicitor spray) (A), pathogen control plants (plants inoculated with only Foph) (B), Foph-inoculated plants with three foliar brassinosteroids (BR) applications (C), Foph-inoculated plants with three foliar salicylic acid (SA) applications (D), Foph-inoculated plants with three foliar jasmonic acid (JA) applications (E), and Foph-inoculated plants with three foliar botanical extracts (BE) applications (F) at 50 DAI.

\subsection{Plant Growth Variables}

Significant differences were found between treatments (elicitors and foliar applications number) on leaf area (LA) $(p=0.000)$ and total plant dry weight (TDW) $(p=0.000)$ at 50 DAI. LA and TDW were highly affected by Foph inoculation, recording a lower value in this group of plants (pathogen control). When cape gooseberry plants were sprayed with elicitors, a positive response were observed. In this sense, three BR sprays caused a higher TDW $(9.25 \mathrm{~g})$ and LA $\left(1057.4 \mathrm{~cm}^{2}\right)$ values followed by SA sprayed plants three times ( $8.47 \mathrm{~g}$ for TDW and $856.7 \mathrm{~cm}^{2}$ for LA, respectively) (Figure 4A,B). On the other hand, Foph-inoculated plants treated with JA or BE did not show a significant increase in these growth parameter values at the end of the experiment. Finally, the highest LA $\left(1259.3 \mathrm{~cm}^{2}\right)$ and TDW (10.16 g) were recorded in the absolute (uninfected plants) control (Figure 4).

\subsection{Stomatal Conductance $\left(g_{s}\right)$, Leaf Temperature $\left(T_{L}\right)$ and Leaf Water Potential $\left(\Psi_{w f}\right)$}

Statistical differences were also found between treatments (synthetic elicitors and foliar sprays number) on $\mathrm{g}_{\mathrm{s}}(p=0.000), \mathrm{T}_{\mathrm{L}}(p=0.001)$, and $\Psi_{\mathrm{wf}}(p=0.000)$ at 50 DAI. Uninfected plants and not treated with any elicitor (absolute control) had the highest values in $\mathrm{g}_{\mathrm{s}}\left(263.01 \mathrm{mmol} \mathrm{m}^{-2} \mathrm{~s}^{-1}\right.$ ) (Figure 5A).

In contrast, Foph plants showed the lowest gs $\left(63.58 \mathrm{mmol} \mathrm{m}^{-2} \mathrm{~s}^{-1}\right)$. On the other hand, foliar elicitor sprays helped to increase this variable under inoculate conditions. In general, three foliar synthetic elicitor applications increased $g_{s}$ values by $~ 164 \%$ compared with Foph-inoculated plants without any elicitor treatment. In this sense, plants with three foliar BE, SA, and BR applications showed the highest $\mathrm{g}_{\mathrm{s}}$ values $\left(\sim 184 \mathrm{mmol} \mathrm{m}^{-2} \mathrm{~s}^{-1}\right)$, followed by Foph-inoculated plants with two SA (174.1 mmol m $\left.\mathrm{mm}^{-2} \mathrm{~s}^{-1}\right), \mathrm{BE}\left(145.2 \mathrm{mmol} \mathrm{m}^{-2} \mathrm{~s}^{-1}\right)$ and BR $\left(144.6 \mathrm{mmol} \mathrm{m}^{-2} \mathrm{~s}^{-1}\right)$ sprays (Figure 5A). JA sprays enhanced $g_{s}$ values to a lesser extent in Foph-inoculated cape gooseberry plants.

Regarding $\mathrm{T}_{\mathrm{L}}$, opposite results were found in comparison with $\mathrm{g}_{\mathrm{s}}$ in which the higher $\mathrm{T}_{\mathrm{L}}$ was recorded in Foph plants (pathogen control). Three foliar BR, $\mathrm{SA}$, and BE sprays reduced $\mathrm{T}_{\mathrm{L}}$ values in Foph-inoculated cape gooseberry plants $\left(19.9,20.3\right.$ and $20.6^{\circ} \mathrm{C}$, respectively) compared with inoculated plants without any synthetic elicitors $\left(23.5^{\circ} \mathrm{C}\right)$ (Figure $\left.5 \mathrm{~B}\right)$. On the other hand, foliar JA applications 
also generated a slight reduction in $\mathrm{T}_{\mathrm{L}}$ values $\left(21.6{ }^{\circ} \mathrm{C}\right)$ (Figure $\left.5 \mathrm{~B}\right)$. Finally, the most negative $\Psi_{\mathrm{wf}}$ values were recorded in plants only inoculated with Foph and without any foliar elicitor application $(\sim-0.6 \mathrm{Mpa}) . \Psi_{\mathrm{wf}}$ values were enhanced with the increase in the number of foliar elicitor sprays (mainly BR, SA or BE) (Figure 6). It was evidenced that the highest $\Psi_{\mathrm{wf}}$ values were also recorded in absolute control $(-0.21 \mathrm{Mpa})$. Foliar JA applications in Foph-inoculated plants showed a slight increase in the $\Psi_{\mathrm{wf}}$ (Figure 6).

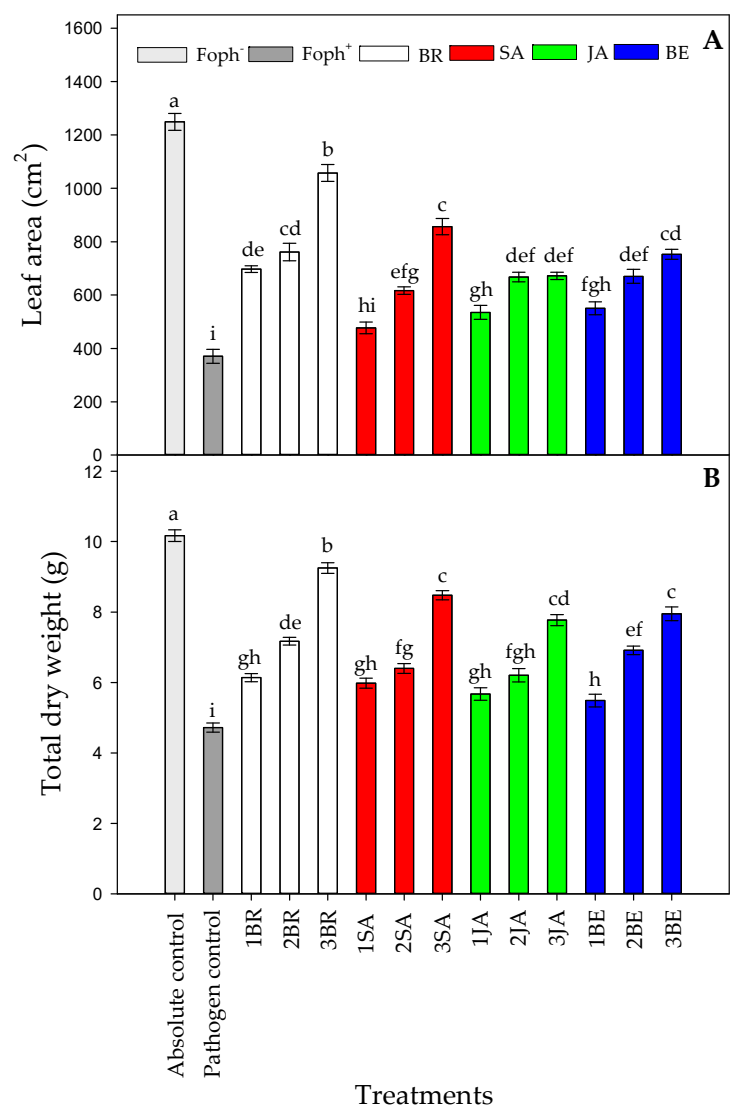

Figure 4. Effect of the different number of sprays (0,1,2 and 3 applications) of synthetic elicitors (Salicylic acid (SA), jasmonic acid (JA), Brassinosteroids (BR), or botanical extracts (BE)) on leaf area (LA) (A) and total dry weight (TDW) (B) in Fusarium oxysporum f. sp. physali (Foph ${ }^{+}$) infected cape gooseberry (Physalis peruviana L.) plants at 50 DAI. Data represent the average of ten plants \pm SE per treatment $(n=10)$. Bars followed by different letters indicate statistically significant differences according to the Tukey test $(p \leq 0.05)$. 


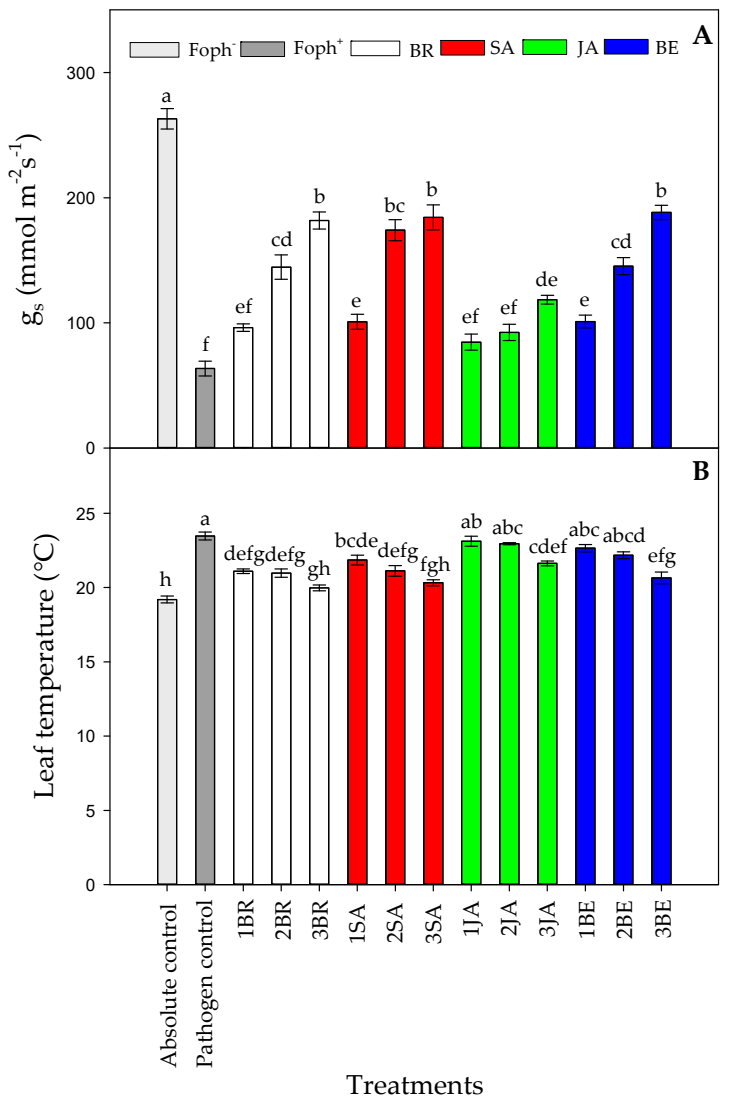

Figure 5. Effect of the different number of sprays (0, 1, 2 and 3 applications) of synthetic elicitors (Salicylic acid (SA), jasmonic acid (JA), Brassinosteroids (BR), or botanical extracts (BE)) on stomatal conductance $\left(\mathrm{g}_{\mathrm{s}}\right)(\mathbf{A})$ and leaf temperature $\left(\mathrm{T}_{\mathrm{L}}\right)\left(\right.$ B) in Fusarium oxysporum $\mathrm{f}$. sp. physali $\left(\mathrm{Foph}^{+}\right)$infected cape gooseberry (Physalis peruviana L.) plants at 50 DAI. Data represent the average of ten plants $\pm \mathrm{SE}$ per treatment $(n=10)$. Bars followed by different letters indicate statistically significant differences according to the Tukey test $(p \leq 0.05)$.

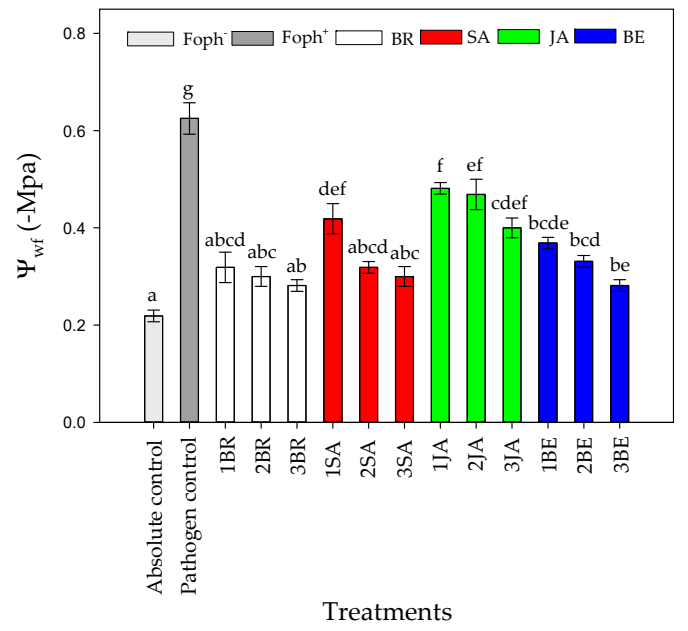

Figure 6. Effect of the different number of sprays (0, 1, 2, and 3 applications) of synthetic elicitors (Salicylic acid (SA), jasmonic acid (JA), Brassinosteroids (BR), or botanical extracts (BE)) on leaf water potential $\left(\Psi_{\mathrm{wf}}\right)$ in Fusarium oxysporum $\mathrm{f}$. sp. physali $\left(\mathrm{Foph}^{+}\right.$) infected cape gooseberry (Physalis peruviana L.) plants at 50 DAI. Data represent the average of ten plants \pm SE per treatment $(n=10)$. Bars followed by different letters indicate statistically significant differences according to the Tukey test $(p \leq 0.05)$. 


\subsection{Parameters of Maximum Photochemical Efficiency of PSII $\left(F_{v} / F_{m}\right)$ and Rapid Light-Response Curves}

Significant differences $(p=0.000)$ were obtained between evaluated treatments (elicitors and number of applications) on $\mathrm{F}_{\mathrm{v}} / \mathrm{F}_{\mathrm{m}}$ ratio at 50 DAI. It was recorded that Foph-inoculated plants with or without any application of synthetic elicitors also recorded the lowest $\mathrm{F}_{\mathrm{v}} / \mathrm{F}_{\mathrm{m}}$ values $(\sim 0.44)$, while an increase of this ratio was obtained with a greater number of foliar elicitor sprays. In general, three foliar BR, SA, JA and BE applications caused a positive effect on the PSII photochemical efficiency, obtaining values between 0.7 and 0.77 (similar values were observed in absolute control) (Figure 7).

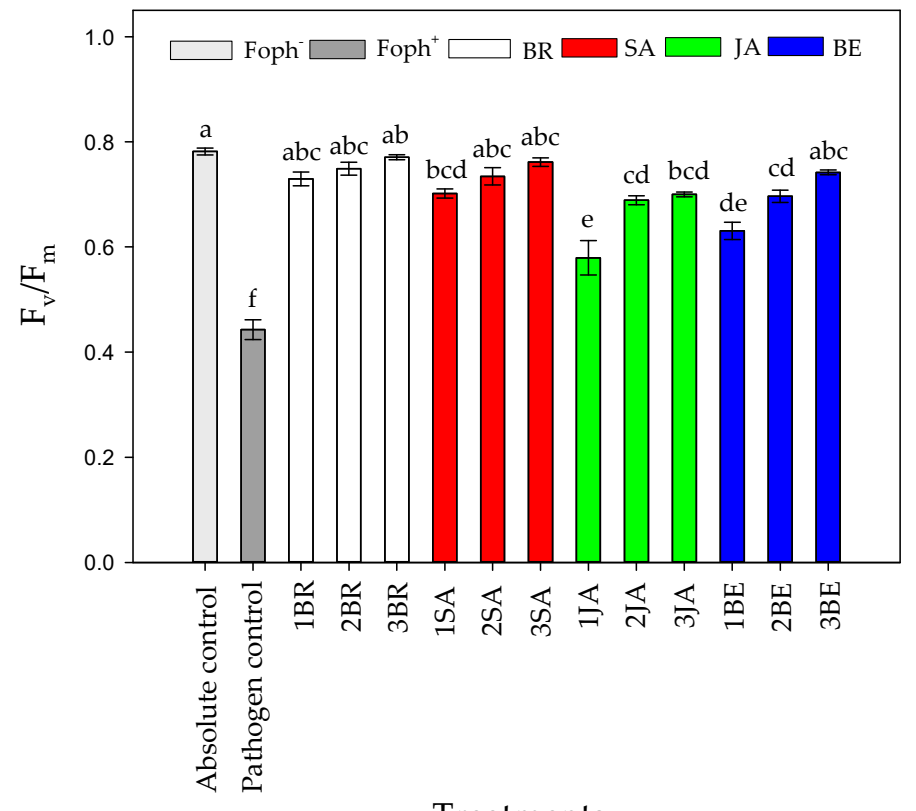

Treatments

Figure 7. Effect of the different number of sprays (0, 1, 2 and 3 applications) of synthetic elicitors (Salicylic acid (SA), jasmonic acid (JA), Brassinosteroids (BR), or botanical extracts (BE)) on maximum photochemical efficiency of PSII $\left(\mathrm{F}_{\mathrm{v}} / \mathrm{F}_{\mathrm{m}}\right)$ in Fusarium oxysporum $\mathrm{f}$. sp. physali $\left(\mathrm{Foph}^{+}\right)$-infected cape gooseberry (Physalis peruviana L.) plants at 50 DAI. Data represent the average of ten plants \pm SE per treatment $(n=10)$. Bars followed by different letters indicate statistically significant differences according to the Tukey test $(p \leq 0.05)$.

Differences were also obtained on the parameters derived from the rapid light-response curves ( $\alpha$ $(p=0.000), \operatorname{ETR}_{\max }(p=0.000)$ and $\left.\mathrm{I}_{\mathrm{k}}(p=0.000)\right)$ at the end of the experiment. A linear trend $(p \leq 0.001)$ was observed on $\alpha$ and ETR $\max$ in the interaction between inoculation and synthetic elicitors application in which these two parameters were generally favored by the increase in the number of foliar elicitor sprays (Table 1). Finally, a directly proportional relationship was shown between $\mathrm{I}_{\mathrm{k}}$ and the number of foliar applications of each synthetic elicitor. In this regard, $\mathrm{I}_{\mathrm{k}}$ showed a quadratic trend with the use of $\mathrm{BR}$ $(p \leq 0.001)$ and SA $(p \leq 0.01)$, obtaining a higher reading with three foliar applications. Meanwhile, JA and BE presented a linear trend on $\mathrm{I}_{\mathrm{k}}(p \leq 0.05$ and $p \leq 0.001$, respectively) (Table 1$)$. 
Table 1. Effect of the interaction between synthetic elicitors (Salicylic acid (SA), jasmonic acid (JA), Brassinosteroids (BR), or botanical extracts (BE)) and the sprays number $(0,1,2$ and 3 applications) on the rapid light-response curve parameters (initial slope of the curve $(\alpha)$, maximum electron transport rate $\left(\mathrm{ETR}_{\max }\right)$ and minimum saturation irradiance $\left(\mathrm{I}_{\mathrm{k}}\right)$ ) in Fusarium oxysporum $\mathrm{f}$. sp. physali infected cape gooseberry (Physalis peruviana L.) plants at 50 DAI.

\begin{tabular}{|c|c|c|c|c|}
\hline \multicolumn{2}{|c|}{ Treatments } & \multicolumn{3}{|c|}{ Rapid Light-Response Curve Parameters } \\
\hline \multirow{3}{*}{ Elicitor } & \multirow{3}{*}{ Spray number } & $\alpha$ & ETR $_{\max }$ & $\mathbf{I}_{\mathbf{k}}$ \\
\hline & & $\mu \mathrm{mol} \cdot \mathrm{m}^{-2} \cdot \mathrm{s}^{-1}$ & & $\mu \mathrm{mol} \cdot \mathrm{m}^{-2} \cdot \mathrm{s}^{-1}$ \\
\hline & & & 1 & \\
\hline \multirow{4}{*}{$\mathrm{BR}$} & 0 & $0.36^{1}$ & 4.21 & 10.27 \\
\hline & 1 & 0.44 & 6.21 & 14.16 \\
\hline & 2 & 0.59 & 7.09 & 11.85 \\
\hline & 3 & 0.82 & 10.81 & 12.82 \\
\hline \multirow[t]{2}{*}{ Significance $^{2}$} & & $\mathrm{~L}, \mathrm{Q} * * *$ & $\mathrm{~L}^{* * *}$ & $Q, C^{* * *}$ \\
\hline & 0 & 0.36 & 4.16 & 10.32 \\
\hline \multirow{3}{*}{ SA } & 1 & 0.44 & 6.04 & 13.68 \\
\hline & 2 & 0.57 & 7.47 & 13.07 \\
\hline & 3 & 0.80 & 10.01 & 12.69 \\
\hline \multirow[t]{2}{*}{ Significance } & & $\mathrm{L}^{* * *}$ & $\mathrm{~L}^{* * *}$ & $Q^{* *}$ \\
\hline & 0 & 0.37 & 4.19 & 10.25 \\
\hline \multirow{3}{*}{ JA } & 1 & 0.42 & 4.37 & 10.03 \\
\hline & 2 & 0.55 & 5.92 & 10.79 \\
\hline & 3 & 0.63 & 7.12 & 11.24 \\
\hline \multirow[t]{2}{*}{ Significance } & & $\mathrm{L}^{* * *}$ & $\mathrm{~L}^{* * *}$ & $\mathrm{~L}^{*}$ \\
\hline & 0 & 0.36 & 4.24 & 10.32 \\
\hline \multirow{3}{*}{$\mathrm{BE}$} & 1 & 0.43 & 5.29 & 11.82 \\
\hline & 2 & 0.59 & 7.05 & 11.99 \\
\hline & 3 & 0.75 & 9.39 & 12.43 \\
\hline Significance & & $\mathrm{L}^{* * *}$ & $\mathrm{~L}^{* * *}$ & $\mathrm{~L}^{* * *}$ \\
\hline $\mathrm{CV}^{3}(\%)$ & & 5.7 & 5.83 & 6.89 \\
\hline
\end{tabular}

${ }^{1}$ Data represent the average of ten plants per treatment $(n=10) .{ }^{2 *}, * *$ and ${ }^{* * *}$. differ significantly in $0.05,0.01$ and 0.001 , respectively. $\mathrm{L}=$ linear, $\mathrm{Q}=$ quadratic and $\mathrm{C}=$ cubic. ${ }^{3}$ Coefficient of variation.

\subsection{Leaf Photosynthetic Pigments}

Figure 8 summarizes the leaf photosynthetic pigments content (total chlorophyll (TChl) and carotenoids $(\mathrm{Cx}+\mathrm{c})$ content). Significant differences $(p=0.000)$ were also found on the leaf photosynthetic pigments between treatments (elicitors and sprays number) at the end of the experiment. In general, leaf photosynthetic pigments also increased with the number of foliar synthetic elicitor applications in Foph-inoculated plants (Figure 8). In this sense, it was observed that leaf photosynthetic pigment contents were mainly favored by three foliar BR $\left(1881.8 \mathrm{mg} \mathrm{g}^{-1} \mathrm{FW}\right.$ for TChl and $594.1 \mathrm{mg} \mathrm{g}^{-1}$ FW for $\mathrm{Cx}+\mathrm{c})$, BE (1679.7 $\mathrm{mg} \mathrm{g}^{-1} \mathrm{FW}$ for TChl and $580.6 \mathrm{mg} \mathrm{g}^{-\mathrm{v} 1} \mathrm{FW}$ for $\left.\mathrm{Cx}+\mathrm{c}\right)$, or SA $\left(1616.7 \mathrm{mg} \mathrm{g}^{-1} \mathrm{FW}\right.$ for $\mathrm{TChl}$ and $504.3 \mathrm{mg} \mathrm{g}^{-1} \mathrm{FW}$ for $\mathrm{Cx}+\mathrm{c}$ ) sprays in Foph-inoculated cape gooseberry plants, observing similar leaf photosynthetic contents obtained in absolute control plants $\left(1831.5 \mathrm{mg} \mathrm{g}^{-1} \mathrm{FW}\right.$ for TChl and $521.4 \mathrm{mg} \mathrm{g}^{-1} \mathrm{FW}$ for $\left.\mathrm{Cx}+\mathrm{c}\right)$. Finally, the lowest TChl and $\mathrm{Cx}+\mathrm{c}$ was found in pathogen control (Foph plants) (Figure 8A,B). 


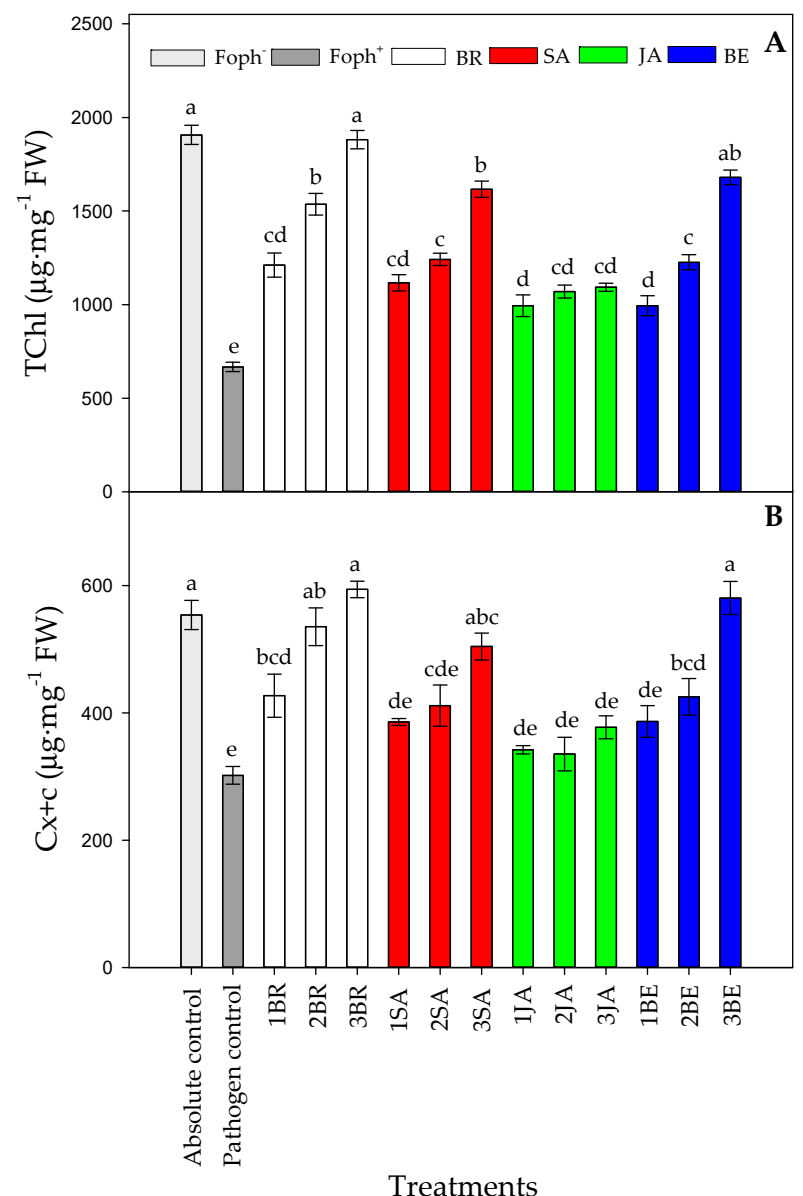

Figure 8. Effect of the different number of sprays (0, 1, 2 and 3 applications) of synthetic elicitors (Salicylic acid (SA), jasmonic acid (JA), Brassinosteroids (BR), or botanical extracts (BE)) on leaf total chlorophyll content (A) and leaf carotenoid contents (B) in Fusarium oxysporum f. sp. physali (Foph ${ }^{+}$) infected cape gooseberry (Physalis peruviana L.) plants at 50 DAI. Data represent the average of ten plants \pm SE per treatment $(n=10)$. Bars followed by different letters indicate statistically significant differences according to the Tukey test $(p \leq 0.05)$.

\subsection{MDA Production and Leaf Proline Content}

MDA production $(p=0.000)$ and proline content $(p=0.000)$ were also affected by the treatments at 50 DAI. A lower lipid peroxidation was observed with the increase in foliar BE, BR or SA applications, obtaining similar values observed in uninfected plants (absolute control) (Figure 9A). On the other hand, a greater proline synthesis was mainly observed in Foph-inoculated cape gooseberry plants and treated with three foliar BR, SA or BE sprays. However, foliar JA applications did not cause any noticeable effect on proline production (Figure 9B). 


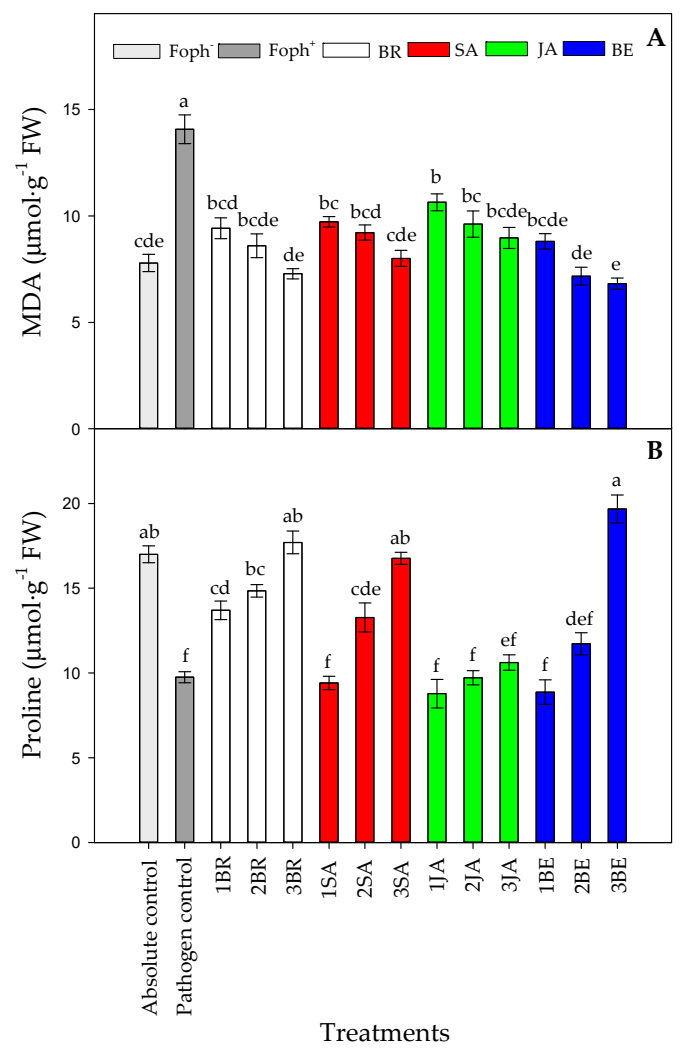

Figure 9. Effect of the different number of sprays (0,1,2 and 3 applications) of synthetic elicitors (Salicylic acid (SA), jasmonic acid (JA), Brassinosteroids (BR), or botanical extracts (BE)) on malondialdehyde (MDA) (A) and proline content (B) in Fusarium oxysporum f. sp. physali $\left(\mathrm{Foph}^{+}\right)$infected cape gooseberry (Physalis peruviana L.) plants at 50 DAI. Data represent the average of ten plants \pm SE per treatment $(n=10)$. Bars followed by different letters indicate statistically significant differences according to the Tukey test $(p \leq 0.05)$.

\subsection{Biplot Analysis of Physiological and Biochemical Responses to Foph Management with Synthetic Elicitors}

The principal component analysis (PCA) showed that the variables evaluated at 50 DAI explained $88.8 \%$ of the physiological and biochemical responses of Foph-inoculated cape gooseberry plants and treated with synthetic elicitors sprays (Figure 10). The variables are represented by vectors, while the elicitors and sprays number are identified by points. The vectors of $g_{s}, T_{L}, \Psi_{w f}$, growth (TDW and LA), fluorescence parameters $\left(\mathrm{F}_{\mathrm{v}} / \mathrm{F}_{\mathrm{m}}, \alpha, \mathrm{ETR}_{\max }\right.$ and $\mathrm{I}_{\mathrm{k}}$ ) and biochemical readings (TChl, $\mathrm{Cx}+\mathrm{c}$, MDA and proline) have angles close to the origin, showing that there is a high correlation between plant physiological behavior and these variables. It was observed that non-Foph-inoculated plants and without any elicitor sprays (control plants) form a single group (V). In contrast, Foph-inoculated plants and untreated (No foliar elicitor applications) (group I) are located in the sector opposite to group V, showing a negative effect of Foph presence on plant physiological and biochemical responses. On the other hand, three differential effects were observed due to elicitor sprays: (i) Foph-inoculated plants and sprayed with JA (one and two applications) or one application of SA or BE (group II) behaved similarly to group I; (ii) three applications of JA, two applications of SA or BE and one application of BR (group III) had a minor positive effect on plant physiology in inoculated plants, whereas (iii) Foph-inoculated plants with three BR, SA or BE sprays (group IV) presented the best physiological and biochemical response showing a behavior close to group II (Figure 10). The three-dimensional plot (percentage efficacy, proline, and $\mathrm{g}_{\mathrm{s}}$ ) corroborated the bi-plot analysis in which the correlation between physiological, agronomic, and biochemical variables showed that three applications of synthetic elicitors (BR, SA or BE) may ameliorate the disease level. These may be considered both responses against pathogens or stress mitigation via physiological processes (Figure 11). 


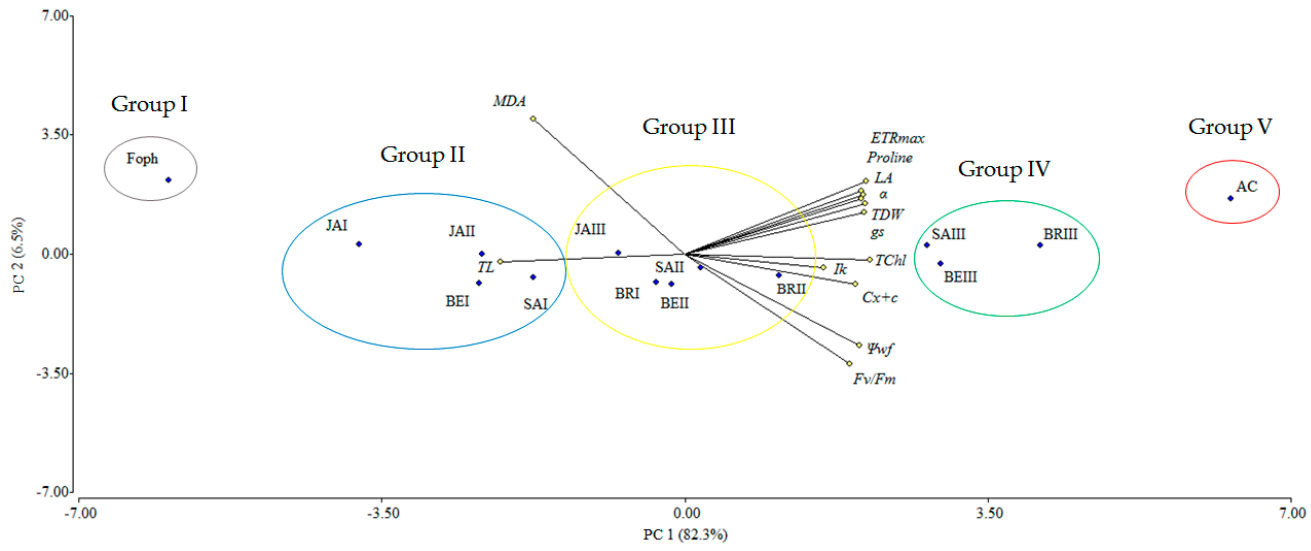

Figure 10. Effect of the different number of sprays (0,1,2 and 3 applications) of synthetic elicitors (Salicylic acid (SA), jasmonic acid (JA), Brassinosteroids (BR), or botanical extracts (BE)) on the biplot analysis of cape gooseberry plants inoculated with Fusarium oxysporum f. sp. physali at 50 days after inoculation (DAI). Abbreviations: AC, absolute control (Non-inoculated plants and without any synthetic elicitor spray); Foph, plants inoculated with only Foph without any synthetic elicitor spray; BRI, Foph-inoculated plants with one foliar BR application; BRII, Foph-inoculated plants with two foliar BR applications; BRIII, Foph-inoculated plants with three foliar BR applications; SAI, Foph-inoculated plants with one foliar SA application; SAII, Foph-inoculated plants with two foliar SA applications; SAIII, Foph-inoculated plants with three foliar SA applications; JAI, Foph-inoculated plants with one foliar JA application; JAII, Foph-inoculated plants with two foliar JA applications; JAIII, Foph-inoculated plants with three foliar JA applications; BEI, Foph-inoculated plants with one foliar BE application; BEII, Foph-inoculated plants with two foliar BE applications; BEIII, Foph-inoculated plants with three foliar BE applications; PC, principal component.

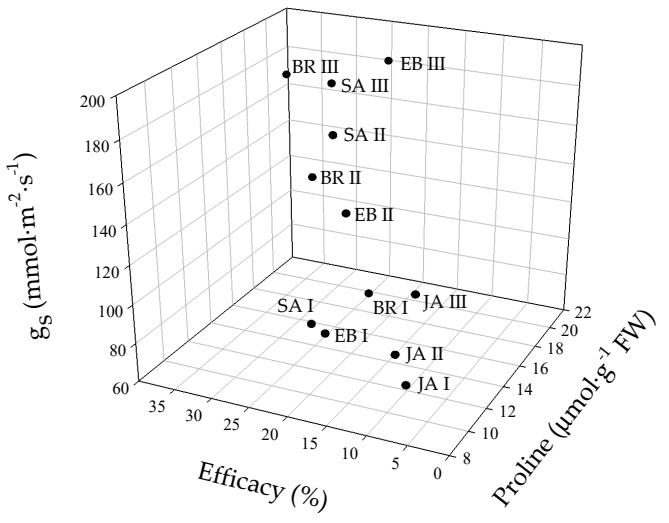

Figure 11. Three-dimensional plot (percentage efficacy, proline, and $g_{s}$ ) for cape gooseberry plants inoculated with Fusarium oxysporum $\mathrm{f}$. sp. physali $\left(\mathrm{Foph}^{+}\right.$) and foliar applications with synthetic elicitors of resistance (brassinosteroids (BR), salicylic acid (SA), jasmonic acid (JA) or botanical extracts (BE)) at 50 days after inoculation (DAI). The data represent the mean of five data points. Abbreviations: BRI, Foph-inoculated plants with one foliar BR application; BRII, Foph-inoculated plants with two foliar BR applications; BRIII, Foph-inoculated plants with three foliar BR applications; SAI, Foph-inoculated plants with one foliar SA application; SAII, Foph-inoculated plants with two foliar SA applications; SAIII, Foph-inoculated plants with three foliar SA applications; JAI, Foph-inoculated plants with one foliar JA application; JAII, Foph-inoculated plants with two foliar JA applications; JAIII, Foph-inoculated plants with three foliar JA applications; BEI, Foph-inoculated plants with one foliar BE application; BEII, Foph-inoculated plants with two foliar BE applications; BEIII, Foph-inoculated plants with three foliar BE applications. 


\section{Discussion}

The effect of elicitors on the management of plant diseases may involve complex metabolic and molecular processes [13]. However, the objective of this study was to evaluate options with a practical application from the agronomic and physiological points of view. Studies to find complementary alternatives to manage vascular wilt caused by Foph in Andean fruit crops have been limited to the use of fungicides and have been recently focused on biological control agents $[7,8]$. Therefore, our research demonstrated the potential use of BR, SA or BE for Foph control in cape gooseberry. Three sprays of these synthetic elicitors decreased the progress of vascular wilt caused by Foph, as evidenced by the significant reduction of the AUDPC, vascular wilt index and vascular browning. Studies performed by Mandal et al. [17] and Rongai et al. [55] showed that a lower vascular wilt severity caused by F. oxysporum f.sp. lycopersici was observed when SA or BE were used in tomato (Solanum lycopersicum L.) plants, respectively. Likewise, browning of the vascular tissue is strong evidence of fusarium wilt [56]. In this sense, studies have shown that vascular browning indicates is good indicator of plant pathogenicity [57] Finally, it has been reported thar foliar BR application reduced vascular wilt severity caused by F. oxysporum f. sp. cucumerinum in cucumber (Cucumis sativus L.) plants [21].

Plant resistance induction under abiotic and biotic stress conditions can be regulated by physiological, biochemical and molecular mechanisms [13,58]. Similarly, these plant resistance responses can be stimulated by exogenous synthetic elicitors application $[59,60]$. The present study showed that the foliar application of synthetic elicitors, mainly BR $\left(1 \mathrm{~mL} \mathrm{~L}^{-1}\right), \mathrm{SA}\left(100 \mathrm{mg} \mathrm{L}^{-1}\right)$ or BE $\left(2.5 \mathrm{~mL} \mathrm{~L}^{-1}\right)$, helped to mitigate the negative effects caused by Foph by favoring physiological and biochemical responses in cape gooseberry plants.

Three foliar applications of BR, SA or BE favored physiological variables such as $g_{s}, \Psi_{w f}$, growth (TDW and LA) and chlorophyll fluorescence parameters $\left(\mathrm{F}_{\mathrm{v}} / \mathrm{F}_{\mathrm{m}}, \mathrm{ETR}_{\max }, \mathrm{I}_{\mathrm{k}}\right.$ and $\left.\alpha\right)$ in Foph-inoculated cape gooseberry plants (Figures 4-7; Table 1). Bibi et al. [61] observed that cotton (Gossypium hirsutum L.) plants infected with Verticillium dahliae and sprayed with BR showed better leaf gas exchange parameters (leaf photosynthesis and transpiration), photochemical efficiency of PSII and greater dry matter accumulation (aerial part and roots) compared with plants without BR application. On the other hand, the positive effect of foliar SA sprays $\left(100 \mathrm{mg} \mathrm{L}^{-1}\right)$ has also been reported for pathogens such as Phytophthora infestans Mont. De Barry in tomato (Solanum lycopersicum L.) plants, favoring plant height and dry matter accumulation compared with diseased and untreated plants with SA [62]. Finally, Parvu et al. [63] recorded that tulip (Tulipa gesneriana L.) plants inoculated with Botrytis tulipae and treated with botanical extracts with high phenolic compound concentrations increased leaf transpiration and stomatal conductance compared with plants only with inoculation.

A higher leaf chlorophyll content after exogenous BR application has been also reported by several authors under biotic stress by plant pathogens. For example, Bibi et al. [64] observed that leaf chlorophyll $\mathrm{a}$ and $\mathrm{b}$ and carotenoids values in cotton (Gossypium hirsutum L.) plants infected with Verticillium dahliae and sprayed with BR were higher in comparison to diseased plants without BR. Biochemical markers such as MDA production, proline content and leaf photosynthetic pigments concentration are widely used to assess the plant response to conditions of abiotic or biotic stress [65-67].

Ding et al. [21] also reported a decrease in MDA production in cucumber (Cucumis sativus L.) plants inoculated with F. oxysporum f. sp. cucumerinum after foliar BR application. In addition, foliar BR application significantly increased proline values in cotton (Gossypium hirsutum L.) plants inoculated with Verticillium dahlia [61]. On the other hand, Zehra et al. [68] also observed a positive effect on the content of leaf photosynthetic pigments and proline in tomato (Solanum lycopersicum L.) plants affected by F. oxysporum f. sp. lycopersici after foliar treatment with SA. Also, SA application caused a significant decrease of MDA production in broad bean (Vicia faba L.) plants infected with Bean yellow mosaic virus (BYMV) [69]. Finally, Naz et al. [70] reported that wheat (Triticum aestivum L.) plants infected with Bipolaris sorokiniana and treated with $\mathrm{BE}$ rich in phenolic compounds showed an increase in the total chlorophyll content and antioxidant activity compared with diseased plants without exogenous BE application. 
In this study, it was found that BR mitigated the negative effects caused by Foph by improving water relations, stomatal opening, and biochemical parameters, and decreasing vascular browning. This positive response can be associated to the fact that BR participate in the osmotic adjustment, promoting the accumulation of soluble carbohydrates such as starch and sucrose [71]. Additionally, BR applications favor the induction of SAR through the expression of enzymes such as $\beta$-1,3-glucanases, chitinases and peroxidases [31,72]. In this investigation, BR enhanced chlorophyll fluorescence parameters $\left(\mathrm{F}_{\mathrm{v}} / \mathrm{F}_{\mathrm{m}}, \mathrm{ETR}_{\max }, \alpha, \mathrm{I}_{\mathrm{k}}\right)$ in Foph-inoculated cape gooseberry plants. BR could cause a better chlorophyll parameter under disease conditions, since this plant hormone has a beneficial effect on PSII reaction centers, improving energy capture [73,74]. Also, the positive effects of exogenous BR applications could be related to the induction of expression of proline synthesis genes that favor a higher proline content, ROS scavenging, and plant cell membrane stability [75].

SA applications also decreased the severity of vascular wilt in Foph-inoculated cape gooseberry plants, which could be due to the positive regulation of genes that are coded for pathogenesis-related (PR) proteins, programmed cell death and ROS induction that help the signaling of plant defense mechanisms [75-78]. Likewise, SA showed a promoter effect of plant growth (TDW and LA) probably due to the fact that this molecule induces cell division and the biosynthesis of organic compounds, and increases nutrients availability and mobility [79]. A better plant water status (expressed as leaf water potential) in Foph-inoculated plants is due to the fact that SA enhances the accumulation of osmotic compounds such as soluble sugars and proline [80]. In the present study, SA applications also favored the leaf TChl content, since this plant hormone inhibits the activity of the enzyme ACC synthase, preventing ethylene formation and chlorophyll degradation [81]. Ghasemzadeh and Jaafar [82] stated that SA can also increase the antioxidant enzymes activity (expressed as a low MDA production) and leaf proline content under stress conditions, which was also observed in this study. These same authors also reported that SA helps the PSII reaction centers stability and the structure of enzymes such as Rubisco structures under stress conditions. Also, it is known that SA may induce resistance to Tobacco mosaic virus in part by enhancing the antioxidant capacity of the host plant $[83,84]$. Finally, other studies have also corroborated the role of SA in the defense mechanisms of plants is associated with the increase of phenolic and flavonoid compounds, reducing the damage caused by lipid peroxidation [85].

Three BE sprays reduced the vascular wilt parameters because BE can have antifungal activity since these extracts are constituted of secondary metabolites such as alkaloids, flavonoids, terpenoids and phenolic compounds. These metabolites can work as precursors of structural polymers such as lignin, or serve as signaling molecules $[38,86]$. In addition, BE sprays had a stimulating effect on all the physiological parameters evaluated in Foph-infected cape gooseberry plants. It has been reported that $\mathrm{BE}$ are considered biostimulants which can improve growth and total photosynthesis causing a greater plant biomass $[87,88]$. Furthermore, BE can favor the plant primary metabolism, causing an increase of free amino acids, proteins, carbohydrates, photosynthetic pigments levels and enzymatic activity [89].

A lower control of vascular wilt was observed in Foph-infected cape gooseberry plants and treated with JA compared with other elicitors. However, opposite results have been observed with this molecule, in which exogenous application has caused a decrease in the progress of diseases such as charcoal rot caused by Macrophomina phaseolina in forage legume (Medicago truncatula) plants [90], Alternaria porri f. sp. solani in tomato (Solanum lycopersicum L.) [91] and Botrytis cinerea in grapes (Vitis vinifera L. $\times$ Vitis labrusca L.) [92,93]. Several authors have also reported that SA activates plant defense responses against hemibiotrophic pathogens such as F. oxysporum [94-96]. The lack of response in Foph-infected plants and sprayed with JA may be due to the fact that JA is generally more effective against necrotrophic pathogens $[97,98]$. 


\section{Materials and Methods}

\subsection{General Growth Conditions}

An experiment under greenhouse conditions was carried out at the Faculty of Agricultural Sciences of the Universidad Nacional de Colombia, Bogotá ( $\left.4^{\circ} 35^{\prime} 56^{\prime \prime} \mathrm{N}, 74^{\circ} 04^{\prime} 51^{\prime \prime} \mathrm{W}\right)$ between June and October 2018. The environmental conditions during the experiment were: $25 / 20^{\circ} \mathrm{C}$ day/night temperature, $60 \%-80 \%$ relative humidity and a natural photoperiod of $12 \mathrm{~h}\left(1500 \mu \mathrm{mol} \mathrm{m}^{-2} \mathrm{~s}^{-1}\right.$ photosynthetically active radiation at noon). Two-month-old ecotype 'Colombia' (Physalis peruviana L.) seedlings purchased from a local nursery were used. The methodology described by Leslie and Summerell [99] was used to index seedlings to rule out Fusarium oxysporum f. sp. physali (Foph) infection. Then, seedlings were transplanted in $2 \mathrm{~L}$ plastic pots, containing a soil-based substrate (clay loam) and rice husk (3:1 v/v). After plant transplantation, seedlings were daily watered with $50 \mathrm{~mL}$ of a nutrient solution prepared from a complete liquid fertilizer (Nutriponic ${ }^{\circledR}$, Walco SA, Colombia) at a dose of $5 \mathrm{~mL} \mathrm{~L}^{-1} \mathrm{H}_{2} \mathrm{O}$ until the end of the experiment. The nutrient solution concentration was: $2.08 \mathrm{mM} \mathrm{Ca}$ $\left(\mathrm{NO}_{3}\right)_{2} \cdot 4 \mathrm{H}_{2} \mathrm{O}, 1.99 \mathrm{mM} \mathrm{MgSO} \cdot \cdot 7 \mathrm{H}_{2} \mathrm{O}, 2.00 \mathrm{mM} \mathrm{NH}_{4} \mathrm{H}_{2} \mathrm{PO}_{4}, 10.09 \mathrm{mM} \mathrm{KNO} 3,46.26 \mathrm{nM} \mathrm{H}_{3} \mathrm{BO}_{3}, 0.45 \mathrm{nM}$ $\mathrm{Na}_{2} \mathrm{MoO}_{4} \cdot 2 \mathrm{H}_{2} \mathrm{O}, 0.32 \mathrm{nM} \mathrm{CuSO} \cdot 5 \mathrm{H}_{2} \mathrm{O}, 9.19 \mathrm{nM} \mathrm{MnCl} \cdot 4 \mathrm{H}_{2} \mathrm{O}, 0.76 \mathrm{nM} \mathrm{ZnSO} \cdot \cdot 7 \mathrm{H}_{2} \mathrm{O}$, and $19.75 \mathrm{nM}$ $\mathrm{FeSO}_{4} \cdot \mathrm{H}_{2} \mathrm{O}$. Finally, the water volume used was obtained by means of the daily quantification of plant evapotranspiration needs using the gravimetric technique described by Hainaut et al. [100].

\subsection{Plant Inoculation and Resistance Elicitors Application}

The inoculum used in the present experiment was the Foph-Map5 strain supplied by the Biological Control Laboratory of the Corporación Colombiana de Investigación Agropecuaria (Agrosavia, Mosquera, Colombia). Young mycelium segments from the supplied strain were cultured in $50 \mathrm{~mL}$ of Potato Dextrose Broth (PDB; Difco ${ }^{\mathrm{TM}}$, Becton Dickinson, Sparks, MD, USA) in 250 mL Erlenmeyer flasks. Then, segments were incubated for 7 days under constant agitation in an orbital shaker (Lab-Line, Melrose Park, IL, USA) at $125 \mathrm{rpm}$ and $28^{\circ} \mathrm{C}$ under dark conditions [8].

The methodology described by Park [101] was used to confirm the absence of the pathogen (Foph) in the soil used in the substrate mixture. Subsequently, the inoculation of cape gooseberry seedlings was carried out by the addition of a liquid suspension of $100 \mathrm{~mL}$ of Foph at a concentration of $1 \times 10^{6}$ microconidia $\mathrm{mL}^{-1}$ for each $0.9 \mathrm{~kg}$ of substrate (soil + rice husk), guaranteeing a final concentration of $1 \times 10^{4}$ microconidia $\mathrm{g}^{-1}$ substrate [7]. Finally, two conditions of presence of the pathogen in the substrate (with and without Foph) were obtained.

Seedlings established in inoculated and non-inoculated substrate were sprayed with salicylic acid (SA) at a dose of $100 \mathrm{mg} \mathrm{L}^{-1}$, jasmonic acid (JA) at a dose of $10 \mathrm{~mL} \mathrm{~L}^{-1}$, brassinosteroids (BR) at a dose of $1 \mathrm{~mL} \mathrm{~L}^{-1}$, or commercial elicitor based on botanical extracts (BE) (Loker ${ }^{\circledR}$, Biolchim SpA, Medicina, Bologna, Italy) at a dose of $2.5 \mathrm{~mL} \mathrm{~L}^{-1}$. Synthetic elicitors concentrations were selected based on the available literature about their use on diseases caused by plant pathogens: SA [17,102], Br [21,22], and JA $[19,103]$. BE concentrations were determined following the manufacturer's recommendations. Finally, Table 2 summarizes the characteristics of the elicitors used in this study.

The foliar applications of all the elicitors used were performed at different moments during the experiment: 1) one foliar spray with synthetic elicitors (8 days before plant inoculation (DBI)) (1 spray); 2) two foliar elicitor sprays (8 DBI and at plant transplantation) (2 sprays); 3) three foliar sprays (8 DBI, plant transplantation and 8 days after inoculation (DAI)) (3 sprays), and 4) plants not treated with any elicitors (0 sprays). Additionally, a group of plants without Foph inoculation and without any foliar applications was used as absolute control. A total of 17 treatment groups were obtained and placed in the greenhouse in a completely randomized design where each experimental unit (treatment) consisted of ten plants (repetitions).

In general, the foliar elicitor sprays were carried out between 07:00 and 09:00 $\mathrm{h}$, using a $1.8 \mathrm{~L}$ manual spray pump (Royal Condor ${ }^{\circledR}$ Garden, Colombia) with an application volume per plant of $20 \mathrm{~mL} \mathrm{H}_{2} \mathrm{O}$, on the upper and lower leaf surface. SA was previously dissolved in ethanol (10\%) and 
completed with deionized water to obtain the concentration to be used. JA was dissolved in methanol and completed with deionized water. Finally, BR were also dissolved in deionized water to obtain the concentration to be evaluated. All foliar applications were performed with a Tween ${ }^{\circledR} 20$ (Merck, Darmstadt, Germany) surface tension adjuvant at $0.02 \%(v / v)$. Finally, the experiment lasted 75 days.

Table 2. Chemical name of the active ingredient, commercial name, and manufacturer of the synthetic resistance elicitors used to evaluate the foliar sprays on cape gooseberry plants inoculated with Fusarium oxysporum f. sp. physali (Foph).

\begin{tabular}{cc}
\hline Chemical Name of the Active Ingredient & Commercial Name (Manufacturer) \\
\hline 2-Hydroxybenzoic acid & Salicylic acid (Panreac Applichem, \\
$( \pm)-1 \alpha, 2 \beta-3-O x o-2-($ cis-2 pentenyl) & Barcelona, Spain) \\
Cyclopentylacetic acid & $( \pm)$ - Jasmonic acid (Sigma Aldrich, MO, US) \\
$(25 \mathrm{R})-3 \beta .5 \alpha-$ dihydroxy-spirostan-6-one & Biomex DI-31 (Minerales exclusivos SA, \\
Echinacea, Tormentil and Aloe extracts, & Bogotá, Colombia) \\
$\mathrm{K}$ and Mg salts & Loker $^{\circledR}$ (Biolchim S. p. A., Medicina, \\
Bologna, Italy)
\end{tabular}

\subsection{Analysis of Vascular Wilt Development}

Vascular wilt severity in cape gooseberry seedlings was recorded each three days from plant inoculation to the end of the trial (50 DAI). Disease severity was evaluated using a scale with six levels described by Moreno-Velandia [104], where $0=$ asymptomatic plants; $1=$ slight epinastic response and mild chlorosis of the lower third of the plant; 2 = epinastic response in between $30 \%-50 \%$ of the leaves and moderate chlorosis in mature leaves; $3=$ epinastic response in between $60 \%-80 \%$ of the leaves and moderate chlorosis in the middle third; $4=$ epinastic response in all the leaves of the plant, severe chlorosis and defoliation; $5=$ wilting and severe defoliation, dead plant. The disease severity index was calculated at each evaluation time using Equation (1) described by Townsend and Heuberger [105]:

$$
\text { Disease severity index }=\left(\sum(n v) / V\right)
$$

where $n$ is the level of infection according to the scale, $v$ is the number of plants present in each level and $V$ is the total number of evaluated plants.

Also, the area under the disease progress curve (AUDPC) was estimated in each treatment by the trapezoidal integration method [106,107] using Equation (2):

$$
\operatorname{AUDPC}=\left\{\sum_{i=1}^{n-1}\left[\left(y_{i}+y_{i+1}\right) / 2\right] *\left(t_{i+1}-t_{i}\right)\right\}
$$

where $n$ is the number of evaluations, $y_{i}$ and $y_{i+1}$ are the values of the severity scale that were present at each moment of evaluation and $\left(t_{i+1}-t_{i}\right)$ is the interval of time between evaluations. The presence or absence of Foph in plants of the different inoculated and non-inoculated treatments was confirmed 50 DAI by planting explants from the base of the plant stem in PDA medium (Oxoid, Basingstoke, UK) and incubating them at $25^{\circ} \mathrm{C}$ [99].

Finally, the vascular browning was evaluated at 50 DAI by cutting vertical sections at the stem base in each treatment. The percentage of vascular bundle browning was quantified using a scale of five levels described by Mandal et al. [17], where $1=$ no vascular browning; $2=1-25 \%$ vascular browning; $3=26-50 \%$ vascular browning; $4=51 \%-75 \%$ vascular browning; $5=>75 \%$ vascular browning.

\subsection{Physiological and Biochemical Variables}

All physiological and biochemical variables were assessed at $50 \mathrm{DAI}$ in order to see the effect of the evaluated factors. 


\subsubsection{Stomatal Conductance and Leaf Water Status}

Stomatal conductance $\left(\mathrm{g}_{\mathrm{s}}\right)$ was estimated in the third fully expanded leaf from the upper portion of the canopy using a portable porometer (SC-1, Decagon Devices Inc., Pullman, Washington, WA USA) between 0900 and 1500 hours in totally sunny days. Leaf water status was monitored by measuring the leaf water potential $\left(\Psi_{\mathrm{wf}}\right)$ using a Schollander pressure chamber (PMS Instruments, Albany, OR, USA) on the same leaves used to measure $g_{s}$. Leaf temperature $\left(T_{L}\right)$ was also determined using an infrared thermometer (Cole-Parmer No. 800-323-4340) in plants from all treatments.

\subsubsection{Fv/Fm Ratio and Rapid Light-Response Curves}

The $\mathrm{F}_{\mathrm{v}} / \mathrm{F}_{\mathrm{m}}$ ratio and the rapid light-response curves (RLC) were determined using a modulated fluorometer (MINI-PAM, Walz, Effeltrich, Germany). After $g_{s}$ estimation, the same leaves were acclimated to the dark using lightweight leaf clips for at least $15 \mathrm{~min}$ before measurements were taken. The $\mathrm{F}_{\mathrm{v}} / \mathrm{F}_{\mathrm{m}}$ measurements were performed with a pulse of maximum light intensity of up to $2600 \mu \mathrm{mol}$ $\mathrm{m}^{-2} \mathrm{~s}^{-1}$ on the surface of the leaf. The RLC were constructed by plotting the electron transport rate (ETR) compared with the increase in actinic irradiance (from 1 to $1795 \mu \mathrm{mol} \mathrm{m}^{-2} \mathrm{~s}^{-1}$ ) with intervals of $10 \mathrm{~s}$ between the irradiance levels. In addition, the parameters $\alpha$ (Initial slope), ETR $\max$ (maximum ETR) and $\mathrm{I}_{\mathrm{k}}$ (light saturation parameter) were estimated by the model described by $\mathrm{Xu}$ et al. [108].

\subsubsection{Growth Parameters}

Plants were harvested and their organs were separately weighed. Then, all leaves from each plant in every treatment were photographed with a digital camera (D3300, Nikon, Thailand) and saved as TIFF (Tagged Image File Format) images. LA was calculated from the obtained digital images using Java image processing software (Image J; National Institute of Mental Health, Bethesda, MD). Finally, leaf (LDW), stem (SDW) and root (RDW) dry weights from each plant per treatment were obtained.

\subsubsection{Leaf Photosynthetic Pigments}

The equations described by Wellburn [109] were used to estimate chlorophyll and carotenoid content. Leaf tissue samples $(0.03 \mathrm{~g})$ from the middle part of the canopy were collected and homogenized in $3 \mathrm{~mL}$ of $80 \%$ acetone. Then, the samples were centrifuged (Model 420101, Becton Dickinson Primary Care Diagnostics, MD, USA) at $5000 \mathrm{rpm}$ for $10 \mathrm{~min}$ to remove particles. The supernatant was diluted to a final volume of $6 \mathrm{ml}$ by adding $80 \%$ acetone [110]. The chlorophyll content was determined at 663 and $646 \mathrm{~nm}$, whereas carotenoids were estimated at $470 \mathrm{~nm}$ using a spectrophotometer (Spectronic BioMate 3 UV-vis Thermo, Madison, WI, USA).

\subsubsection{Lipid Peroxidation (malondialdehyde-MDA)}

The thiobarbituric acid (TBA) method described by Hodges et al. [111] was used to estimate membrane lipid peroxidation (MDA). Approximately $0.3 \mathrm{~g}$ of leaf tissue were also homogenized in liquid nitrogen. The samples were centrifuged at $5000 \mathrm{rpm}$, and then the absorbances were measured at 440, 532 and $600 \mathrm{~nm}$ with the spectrophotometer. Finally, an extinction coefficient $\left(157 \mathrm{M} \cdot \mathrm{mL}^{-1}\right)$ was used to obtain the MDA concentration.

\subsubsection{Proline Concentration}

The proline content was determined for all treatments using the method described by Bates et al. [112]. Approximately $0.3 \mathrm{~g}$ of the same leaves collected for the determination of photosynthetic pigments were homogenized in liquid nitrogen and stored for further analysis. Ten $\mathrm{mL}$ of a $3 \%$ aqueous solution of sulfosalicylic acid were added to the stored samples, which were then filtered with Whatman paper (No. 2). Subsequently, $2 \mathrm{~mL}$ of this filtrate were reacted with $2 \mathrm{~mL}$ of ninhydrin acid and $2 \mathrm{~mL}$ of glacial acetic acid. The mixture was placed in a water bath at $90^{\circ} \mathrm{C}$ for $1 \mathrm{~h}$. The reaction was stopped by incubation on ice. The resulting solution was dissolved in $4 \mathrm{~mL}$ of toluene by shaking the test tubes vigorously using a 
vortex shaker and the absorbance readings were determined at $520 \mathrm{~nm}$ with the same spectrophotometer used in the quantification of photosynthetic pigments (Spectronic BioMate 3 UV-Vis, Thermo, Madison, WI, USA). Proline content was calculated using the fresh weight of the sample by means of a standard calibration curve (equation 3).

$$
\frac{\mu \text { mol Proline }}{\text { fresh plant material }}=\frac{\left[\frac{\left(\frac{\mu g \text { Proline }}{m L} \times m L \text { Toluene }\right)}{\frac{115.5 \mu g}{\mu m o l}}\right]}{\left[\frac{g \text { sample }}{5}\right]}
$$

\subsection{Experimental Design and Data Analysis}

Data were analyzed by two experimental designs. A factorial design in which the first factor corresponded to foliar synthetic elicitor (SA, JA, BR and BE) sprays and the second factor was the number of foliar sprays per elicitor (0, 1, 2 and 3 sprays) was used to analysis severity AUDPC, severity index, vascular browning and rapid light response curves. Meanwhile, the physiological and biochemical variables were studied using a completely randomized design (CRD). Each treatment group consisted of 10 plants as repetitions. The percentage values were transformed using the arcsine function. A principal analysis of components was performed with InfoStat 2016 software (analytical software, Universidad Nacional de Córdoba, Argentina) to select the best combination of synthetic elicitors and number of foliar applications under plant infection with Foph. For all analyzes, F-protected data analysis was used and when significant differences were obtained $(p \leq 0.05)$ in the analysis of variance (ANOVA), a Tukey post hoc test was used for the comparison of means. Data were analyzed using Statistix v 9.0 software (Analytical Software, Tallahassee, FL, USA). Figures and three-dimensional plot were performed using Sigmaplot software (version 12.0, Systat Software, San José, CA, USA).

\section{Conclusions}

In summary, this study showed that the use of synthetic elicitors such as BR, SA, or BE improved the physiological and biochemical response in Foph-infected cape gooseberry plants. In this sense, the effectiveness of three foliar BR, SA, or BE sprays was corroborated by three-dimensional plot and biplot analysis, in which it can be shown that stomatal conductance, proline synthesis, and efficacy percentage were accurate parameters to predict Foph control. Therefore, these elicitors can be considered as commercial tools for vascular wilt management, probably minimizing applications of chemical synthesis fungicides. Similarly, it was observed that the use of these elicitors has positive effects on plant physiology, favoring $g_{s}, \Psi_{w f}$, growth (expressed as total plant biomass and LA), PSII efficiency, leaf chlorophyll and proline content, and low lipid membrane peroxidation. However, additional field studies are needed to quantify the effect of synthetic elicitors sprays (BR, SA, or BE) on yield parameters and crop quality in infected plants. The results obtained suggest that exogenous BR, $\mathrm{SA}$, or BE applications in cape gooseberry plants could be considered within integrated management programs of vascular wilt in producing areas.

Author Contributions: Conceptualization, C.C.C.-A. and H.R.-D.; Methodology, C.C.C.-A.; Software, C.C.C.-A.; Validation, C.C.C.-A., S.G.-C. and H.R.-D.; Formal Analysis, C.C.C.-A.; Investigation, C.C.C.-A.; Resources, S.G.-C.; Data Curation, C.C.C.-A.; Writing-Original Draft Preparation, C.C.C.-A.; Writing-Review \& Editing, H.R.-D. and S.G.-C.; Visualization, S.G.-C.; Supervision, H.R.-D.; Project Administration, H.R.-D.; Funding Acquisition, H.R.-D. and S.G.-C. All authors have read and agreed to the published version of the manuscript.

Funding: This research received no external funding.

Conflicts of Interest: The authors declare no conflict of interest. 


\section{References}

1. Fischer, G.; Almanza-Merchán, P.J.; Miranda, D. Importancia y cultivo de la uchuva (Physalis peruviana L.). Rev. Bras. Frutic. 2014, 36,1-15. [CrossRef]

2. Puente, L.A.; Pinto-Muñoz, C.A.; Castro, E.S.; Cortés, M. Physalis peruviana Linnaeus, the multiple properties of a highly functional fruit: A review. Food Res. Int. 2011, 44, 1733-1740. [CrossRef]

3. Ramadan, M.F. Bioactive phytochemicals, nutritional value, and functional properties of cape gooseberry (Physalis peruviana): An overview. Food Res. Int. 2011, 44, 1830-1836. [CrossRef]

4. Erkaya, T.; Dağdemir, E.; Şengül, M. Influence of Cape gooseberry (Physalis peruviana L.) addition on the chemical and sensory characteristics and mineral concentrations of ice cream. Food Res. Int. 2012, 45, 331-335. [CrossRef]

5. Olivares-Tenorio, M.L.; Verkerk, R.; van Boekel, M.A.; Dekker, M. Thermal stability of phytochemicals, HMF and antioxidant activity in cape gooseberry (Physalis peruviana L.). J. Funct. Foods 2017, 32, 46-57. [CrossRef]

6. Agronet. Available online: http://www.agronet.gov.co/estadistica/Paginas/default.aspx (accessed on 1 November 2019).

7. Osorio-Guarín, J.A.; Enciso-Rodríguez, F.E.; González, C.; Fernández-Pozo, N.; Mueller, L.A.; Barrero, L. Association analysis for disease resistance to Fusarium oxysporum in cape gooseberry (Physalis peruviana $\mathrm{L}$ ). BMC Genom. 2016, 17, 248. [CrossRef]

8. Moreno-Velandia, C.A.; Izquierdo-García, L.F.; Ongena, M.; Kloepper, J.W.; Cotes, A.M. Soil sterilization, pathogen and antagonist concentration affect biological control of Fusarium wilt of cape gooseberry by Bacillus velezensis Bs006. Plant Soil 2018, 435, 39-55. [CrossRef]

9. Simbaqueba, J.; Catanzariti, A.; Gonzalez, C.; Jones, D. Evidence for horizontal gene transfer and separation of effector recognition form effector function revealed by analysis of effector genes shared between cape-gooseberry and tomate-infecting formae speciales of Fusarium oxysporum. Mol. Plant Pathol. 2018, 9 , 2302-2318. [CrossRef]

10. Urrea, R.; Cabezas, L.; Sierra, R.; Cárdenas, M.; Restrepo, S.; Jiménez, P. Selection of antagonistic bacteria isolated from the Physalis peruviana rhizosphere against Fusarium oxysporum. J. Appl. Microbiol. 2011, 111, 707-716. [CrossRef]

11. McGovern, R.J. Management of tomato diseases caused by Fusarium oxysporum. Crop. Prot. 2015, 73, 78-92. [CrossRef]

12. Tamm, L.; Thürig, B.; Fliessbach, A.; Goltlieb, A.E.; Karavani, S.; Cohen, Y. Elicitors and soil management to induce resistance against fungal plant diseases. Njas-Wagen. J. Life Sc. 2011, 58, 131-137. [CrossRef]

13. Thakur, M.; Sohal, B.S. Role of elicitors in inducing resistance in plants against pathogen infection: A review. ISRN Biochem. 2013, 1, 762412. [CrossRef]

14. Mejía-Teniente, L.; Torres-Pacheco, I.; González-Chavira, M.M.; Ocampo-Velazquez, R.V.; Herrera-Ruiz, G.; Chapa-Oliver, A.M.; Guevara-González, R.G. Use of elicitors as an approach for sustainable agricultura. Afr. J. Biotechnol. 2010, 9, 9155-9162.

15. Bektas, Y.; Eulgem, T. Synthetic plant defense elicitors. Front. Plant Sci. 2015, 5, 804. [CrossRef] [PubMed]

16. Guimarães, G.H.C.; Dantas, R.L.; de Sousa, A.S.B.; Soares, L.G.; de Sá Melo, R.; da Silva, R.S.; Lima, R.P.; Mendonça, R.M.N.; Beaudry, R.M.; Silva, S.M. Impact of cassava starch-alginate based coatings added with ascorbic acid and elicitor on quality and sensory attributes during pineapple storage. Afr. J. Agric. Res. 2017, 12, 664-673.

17. Mandal, S.; Mallick, N.; Mitra, A. Salicylic acid-induced resistance to Fusarium oxysporum f. sp. lycopersici in tomato. Plant Physiol. Bioch. 2009, 47, 642-649. [CrossRef] [PubMed]

18. Xue, R.F.; Wu, J.; Wang, L.F.; Blair, M.W.; Wang, X.M.; De Ge, W.; Zhu, Z.D.; Wang, S.M. Salicylic acid enhances resistance to Fusarium oxysporum f. sp. phaseoli in common beans (Phaseolus vulgaris L.). J. Plant Growth Regul. 2014, 33, 470-476. [CrossRef]

19. Jaiti, F.; Verdeil, J.L.; El Hadrami, I. Effect of jasmonic acid on the induction of polyphenoloxidase and peroxidase activities in relation to date palm resistance against Fusarium oxysporum f. sp. albedinis. Physiol. Mol. Plant Path. 2009, 74, 84-90. [CrossRef]

20. Zhu, F.; Xi, D.H.; Yuan, S.; Xu, F.; Zhang, D.W.; Lin, H.H. Salicylic acid and jasmonic acid are essential for systemic resistance against tobacco mosaic virus in Nicotiana benthamiana. Mol. Plant Microbe Interact. 2014, 27, 567-577. [CrossRef] 
21. Ding, J.; Shi, K.; Zhou, Y.H.; Yu, J.Q. Effects of root and foliar applications of 24-epibrassinolide on Fusarium wilt and antioxidant metabolism in cucumber roots. HortScience 2009, 44, 1340-1345. [CrossRef]

22. Zhang, D.W.; Deng, X.G.; Fu, F.Q.; Lin, H.H. Induction of plant virus defense response by brassinosteroids and brassinosteroid signaling in Arabidopsis thaliana. Planta 2014, 241, 875-885. [CrossRef] [PubMed]

23. Herrera-Vásquez, A.; Salinas, P.; Holuigue, L. Salicylic acid and reactive oxygen species interplay in the transcriptional control of defense genes expression. Front. Plant Sci. 2015, 6, 171. [CrossRef] [PubMed]

24. Vinod, K.; Sabah, A. Plant Defense against Pathogens: The Role of Salicylic Acid. Res. J. Biotechnol. 2018, 13, 97-103.

25. Le Thanh, T.; Thumanu, K.; Wongkaew, S.; Boonkerd, N.; Teaumroong, N.; Phansak, P.; Buensanteai, N. Salicylic acid-induced accumulation of biochemical components associated with resistance against Xanthomonas oryzae pv. oryzae in rice. J. Plant Interact. 2017, 12, 108-120. [CrossRef]

26. Zhang, Y.; Shi, X.; Li, B.; Zhang, Q.; Liang, W.; Wang, C. Salicylic acid confers enhanced resistance to Glomerella leaf spot in apple. Plant Physiol. Bioch. 2016, 106, 64-72. [CrossRef]

27. Belkhadir, Y.; Jaillais, Y.; Epple, P.; Balsemão-Pires, E.; Dangl, J.L.; Chory, J.L. Brassinosteroids modulate the efficiency of plant immune responses to microbe-associated molecular patterns. Proceeding Natl. Acad. Sci. USA 2012, 109, 297-302. [CrossRef]

28. Wang, Z.Y.; Bai, M.Y.; Oh, E.; Zhu, J.Y. Brassinosteroid signaling network and regulation of photomorphogenesis. Annu. Rev. Genet. 2012, 46, 701-724. [CrossRef]

29. Nawaz, F.; Naeem, M.; Zulfiqar, B.; Akram, A.; Ashraf, M.Y.; Raheel, M.; Shabbir, R.N.; Hussain, R.A.; Anwar, I.; Aurangzaib, M. Understanding brassinosteroid-regulated mechanisms to improve stress tolerance in plants: A critical review. Environ. Sci. Pollut. R. 2017, 24, 15959-15975. [CrossRef]

30. Furio, R.N.; Albornoz, P.L.; Coll, Y.; Zamora, G.M.; Salazar, S.M.; Martos, G.G.; Ricci, J.D. Effect of natural and synthetic Brassinosteroids on strawberry immune response against Colletotrichum acutatum. Eur. J. Plant Pathol. 2018, 153, 167-181. [CrossRef]

31. Canales, E.; Coll, Y.; Hernández, I.; Portieles, R.; García, M.R.; López, Y.; Aranguren, M.; Alonso, E.; Delgado, R.; Luis, M.; et al. 'Candidatus Liberibacter asiaticus', causal agent of citrus Huanglongbing, is reduced by treatment with Brassinosteroids. Plos ONE 2016, 11, e0146223. [CrossRef]

32. Liu, S.; Vargas, J.; Merewitz, E. Jasmonic and salicylic acid effects on bacterial etiolation and decline disease of creeping bentgrass. Crop. Prot. 2018, 109, 9-16. [CrossRef]

33. Conrath, U.; Beckers, G.J.; Flors, V.; García-Agustín, P.; Jakab, G.; Mauch, F.; Newman, M.A.; Pieterse, C.M.J.; Poinssot, B.; Pozo, M.J.; et al. Priming: Getting ready for battle. Mol. Plant Microbe. Interact. 2006, 19, 1062-1071. [CrossRef] [PubMed]

34. Mehari, Z.H.; Elad, Y.; Rav-David, D.; Graber, E.R.; Harel, Y.M. Induced systemic resistance in tomato (Solanum lycopersicum) against Botrytis cinerea by biochar amendment involves jasmonic acid signaling. Plant Soil 2015, 395, 31-44. [CrossRef]

35. Ávila, A.C.; Ochoa, J.; Proaño, K.; Martínez, M.C. Jasmonic acid and nitric oxide protects naranjilla (Solanum quitoense) against infection by Fusarium oxysporum $\mathrm{f}$. sp. quitoense by eliciting plant defense responses. Physiol. Mol. Plant Pathol. 2019, 106, 129-136.

36. Dietrich, R.; Ploss, K.; Heil, M. Growth responses and fitness costs after induction of pathogen resistance depend on environmental conditions. Plant Cell Environ. 2005, 28, 211-222. [CrossRef]

37. Parkinson, L.E.; Crew, K.S.; Thomas, J.E.; Dann, E.K. Efficacy of acibenzolar-S-methyl (Bion®) treatment of Australian commercial passionfruit, Passiflora edulis $\mathrm{f}$. sp. flavicarpa, on resistance to Passionfruit woodiness virus (PWV) and activities of chitinase \& $\beta-1,3$-glucanase. Australas. Plant Path. 2015, 44, 311-318.

38. Akila, R.; Rajendran, L.; Harish, S.; Saveetha, K.; Raguchander, T.; Samiyappan, R. Combined application of botanical formulations and biocontrol agents for the management of Fusarium oxysporum $\mathrm{f}$. sp. cubense (Foc) causing Fusarium wilt in banana. Biol. Control. 2011, 57, 175-183. [CrossRef]

39. Gurjar, M.S.; Ali, S.; Akhtar, M.; Singh, K.S. Efficacy of plant extracts in plant disease management. Agric. Sci. 2012, 3, 425-433. [CrossRef]

40. Li, G.; Zhu, S.; Wu, W.; Zhang, C.; Peng, Y.; Wang, Q.; Shi, J. Exogenous nitric oxide induces disease resistance against Monilinia fructicola through activating the phenylpropanoid pathway in peach fruit. J. Sci. Food Agr. 2017, 97, 3030-3038. [CrossRef]

41. Jayaraman, J.; Norrie, J.; Punja, Z.K. Commercial extract from the brown seaweed Ascophyllum nodosum reduces fungal diseases in greenhouse cucumber. J. Appl. Phycol. 2011, 23, 353-361. [CrossRef] 
42. Shifa, H.; Gopalakrishnan, C.; Velazhahan, R. Management of late leaf spot (Phaeoisariopsis personata) and root rot (Macrophomina phaseolina) diseases of groundnut (Arachis hypogaea L.) with plant growth-promoting rhizobacteria, systemic acquired resistance inducers and plant extracts. Phytoparasitica 2018, 46, 19-30. [CrossRef]

43. Pandey, P.; Ramegowda, V.; Senthil-Kumar, M. Shared and unique responses of plants to multiple individual stresses and stress combinations: Physiological and molecular mechanisms. Front. Plant Sci. 2015, 6, 723. [CrossRef] [PubMed]

44. Irulappan, V.; Senthil-Kumar, M. Morpho-Physiological Traits and Molecular Intricacies Associated with Tolerance to Combined Drought and Pathogen Stress in Plants. In Biotechnologies of Crop. Improvement; Gosal, S.S., Wani, S.H., Eds.; Springer: Cham, Switzerland, 2018; Volume 3, pp. 59-74.

45. Berger, S.; Sinha, A.K.; Roitsch, T. Plant physiology meets phytopathology: Plant primary metabolism and plant-pathogen interactions. J. Exp. Bot. 2007, 58, 4019-4026. [CrossRef] [PubMed]

46. Qamar, A.; Mysore, K.S.; Senthil-Kumar, M. Role of proline and pyrroline-5-carboxylate metabolism in plant defense against invading pathogens. Front. Plant Sci. 2015, 6, 503. [CrossRef] [PubMed]

47. Yusuf, M.; Hayat, S.; Alyemeni, M.N.; Fariduddin, Q.; Ahmad, A. Salicylic Acid: Physiological Roles in Plants. In Salicylic Acid; Hayat, S., Ahmad, A., Alyemeni, M., Eds.; Springer: Dordrecht, Netherlands, 2013; pp. 15-30.

48. Sirhindi, G.; Kumar, M.; Kumar, S.; Bhardwaj, R. Brassinosteroids: Physiology and Stress Management in Plants. In Abiotic stress response in plants; Tuteja, N., Gill, S.S., Eds.; Wiley: Weinheim, Germany, 2016; pp. 279-314.

49. Huang, H.; Liu, B.; Liu, L.; Song, S. Jasmonate action in plant growth and development. J. Exp. Bot. 2017, 68, 1349-1359. [CrossRef]

50. Radwan, D.E.M.; Soltan, D.M. The negative effects of clethodim in photosynthesis and gas-exchange status of maize plants are ameliorated by salicylic acid pretreatment. Photosynthetica 2012, 50, 171-179. [CrossRef]

51. Mahmood, M.; Bidabadi, S.S.; Ghobadi, C.; Gray, D.J. Effect of methyl jasmonate treatments on alleviation of polyethylene glycol -mediated water stress in banana (Musa acuminata cv. 'Berangan', AAA) shoot tip cultures. Plant Growth Regul. 2012, 68, 161-169. [CrossRef]

52. Qiu, Z.; Guo, J.; Zhu, A.; Zhang, L.; Zhang, M. Exogenous jasmonic acid can enhance tolerance of wheat seedlings to salt stress. Ecotoxicol. Environ. Saf. 2014, 104, 202-208. [CrossRef]

53. Fariduddin, Q.; Yusuf, M.; Ahmad, I.; Ahmad, A. Brassinosteroids and their role in response of plants to abiotic stresses. Biol. Plant. 2014, 58, 9-17. [CrossRef]

54. Anwar, A.; Liu, Y.; Dong, R.; Bai, L.; Yu, X.; Li, Y. The physiological and molecular mechanism of brassinosteroid in response to stress: A review. Biol. Res. 2018, 51, 46. [CrossRef]

55. Rongai, D.; Pulcini, P.; Pesce, B.; Milano, F. Antifungal activity of some botanical extracts on Fusarium oxysporum. Open Life Sci. 2015, 10, 409-416. [CrossRef]

56. NC State University Home Page. Available online: https://projects.ncsu.edu/cals/course/pp728/Fusarium/ Fusarium_oxysporum.htm (accessed on 1 November 2019).

57. Ignjatov, M.; Milosevic, D.; Nikolic, Z.; Gvozdanovic-Varga, J.; Jovicic, D.; Zdjelar, G. Fusarium oxysporum as causal agent of tomato wilt and fruit rot. Pestic. Phytomed. 2015, 27, 25-31. [CrossRef]

58. Chakraborty, N.; Ghosh, S.; Chandra, S.; Sengupta, S.; Acharya, K. Abiotic elicitors mediated elicitation of innate immunity in tomato: An ex vivo comparison. Physiol. Mol. Biol. Plants 2016, 22, 307-320. [CrossRef]

59. Jendoubi, W.; Harbaoui, K.; Hamada, W. Salicylic acid-induced resistance against Fusarium oxysporumf.s.pradicis lycopercisi in hydroponic grown tomato plants. J. New Sci. 2015, 21, 985-995.

60. Ramírez-Godoy, A.; Vera-Hoyos, A.P.; Jiménez-Beltrán, N.; Restrepo-Diaz, H. Application of Foliar Synthetic Elicitors for the Management of Diaphorina citri (Hemiptera: Liviidae) Populations in Tahiti Lime (Citrus latifolia Tanaka). HortScience 2018, 53, 1012-1020. [CrossRef]

61. Bibi, N.; Fan, K.; Dawood, M.; Nawaz, G.; Yuan, S.; Xuede, W. Exogenous application of epibrassinolide attenuated Verticillium wilt in upland cotton by modulating the carbohydrates metabolism, plasma membrane ATPases and intracellular osmolytes. Plant Growth Regul. 2013, 73, 155-164. [CrossRef]

62. Tosun, N.; Türküsay, H.; Aktaş, L.; Yavaşoğlu, N.Ü. Effects of salicylic acid, harpin and phosphorus acid in control of late blight (Phytophthora infestans Mont. De Barry) disease and some physiological parameters of tomato. Turk. Phytopathol. Soc. 2006, 32, 1-10.

63. Parvu, M.; Vlase, L.; Fodorpataki, L.; Parvu, O.; Rosca-Casian, O.; Bartha, C.; Barbu-Tudoran, L.; Parvu, A.E. Chemical composition of celandine (Chelidonium majus L.) extract and its effects on Botrytis tulipae (Lib.) Lind fungus and the tulip. Not. Bot. Horti Agrobot. Cluj Napoca 2013, 41, 414-426. [CrossRef] 
64. Bibi, N.; Ahmed, I.M.; Fan, K.; Dawood, M.; Li, F.; Yuan, S.; Wang, X. Role of brassinosteroids in alleviating toxin-induced stress of Verticillium dahliae on cotton callus growth. Environ. Sci. Pollut. R. 2017, 24, 12281-12292. [CrossRef]

65. Kaur, G.; Asthir, B. Proline: A key player in plant abiotic stress tolerance. Biol. Plant. 2015, 59, 609-619. [CrossRef]

66. Khoubnasabjafari, M.; Ansarin, K.; Jouyban, A. Reliability of malondialdehyde as a biomarker of oxidative stress in psychological disorders. BioImpacts 2015, 5, 123-127. [PubMed]

67. Taibi, K.; Taibi, F.; Abderrahim, L.A.; Ennajah, A.; Belkhodja, M.; Mulet, J.M. Effect of salt stress on growth, chlorophyll content, lipid peroxidation and antioxidant defence systems in Phaseolus vulgaris L. S. Afr. J. Bot. 2016, 105, 306-312. [CrossRef]

68. Zehra, A.; Meena, M.; Dubey, M.K.; Aamir, M.; Upadhyay, R.S. Activation of defense response in tomato against Fusarium wilt disease triggered by Trichoderma harzianum supplemented with exogenous chemical inducers (SA and MeJA). Braz. J. Bot. 2017, 40, 651-664. [CrossRef]

69. Radwan, D.E.M.; Fayez, K.A.; Mahmoud, S.Y.; Lu, G. Modifications of antioxidant activity and protein composition of bean leaf due to Bean yellow mosaic virus infection and salicylic acid treatments. Acta Physiol. Plant 2010, 32, 891-904. [CrossRef]

70. Naz, R.; Nosheen, A.; Yasmin, H.; Bano, A.; Keyani, R. Botanical-chemical formulations enhanced yield and protection against Bipolaris sorokiniana in wheat by inducing the expression of pathogenesis-related proteins. PLoS ONE 2018, 13, e0196194. [CrossRef]

71. Lima, J.V.; Lobato, A.K.S. Brassinosteroids improve photosystem II efficiency, gas exchange, antioxidant enzymes and growth of cowpea plants exposed to water deficit. Physiol. Mol. Biol. Plants 2017, 23, 59-72. [CrossRef]

72. Ali, S.S.; Kumar, G.S.; Khan, M.; Doohan, F.M. Brassinosteroid enhances resistance to fusarium diseases of barley. Phytopathology 2013, 103, 1260-1267. [CrossRef]

73. Qiu, Z.; Wang, L.; Zhou, Q. Effects of bisphenol A on growth, photosynthesis and chlorophyll fluorescence in above-ground organs of soybean seedlings. Chemosphere 2013, 90, 1274-1280. [CrossRef]

74. Li, J.; Yang, P.; Gan, Y.; Yu, J.; Xie, J. Brassinosteroid alleviates chilling-induced oxidative stress in pepper by enhancing antioxidation systems and maintenance of photosystem II. Acta Physiol. Plant 2015, 37, 222. [CrossRef]

75. Yadav, S.; Hayat, S.; Wani, A.S.; Irfan, M.; Ahmad, A. Comparison of the Influence of 28-Homobrassinolide and 24-Epibrassinolide on Nitrate Reductase Activity, Proline Content, and Antioxidative Enzymes of Tomato. Int. J. Veg. Sci. 2012, 18, 161-170. [CrossRef]

76. Smith, J.L.; De Moraes, C.M.; Mescher, M.C. Jasmonate-and salicylate-mediated plant defense responses to insect herbivores, pathogens and parasitic plants. Pest Manag. Sci. 2009, 65, 497-503. [CrossRef] [PubMed]

77. Gao, Q.M.; Zhu, S.; Kachroo, P.; Kachroo, A. Signal regulators of systemic acquired resistance. Front. Plant Sci. 2015, 6, 228. [CrossRef] [PubMed]

78. Choi, W.G.; Miller, G.; Wallace, I.; Harper, J.; Mittler, R.; Gilroy, S. Orchestrating rapid long-distance signaling in plants with $\mathrm{Ca}^{2+}$, ROS and electrical signals. Plant J. 2017, 90, 698-707. [CrossRef] [PubMed]

79. Khoshbakht, D.; Asgharei, M.R. Influence of foliar-applied salicylic acid on growth, gas-exchange characteristics, and chlorophyll fluorescence in citrus under saline conditions. Photosynthetica 2015, 53, 410-418. [CrossRef]

80. Razmi, N.; Ebadi, A.; Daneshian, J.; Jahanbakhsh, S. Salicylic acid induced changes on antioxidant capacity, pigments and grain yield of soybean genotypes in water deficit condition. J. Plant Interact. 2017, 12, 457-464. [CrossRef]

81. Nazar, R.; Umar, S.; Khan, N.A.; Sareer, O. Salicylic acid supplementation improves photosynthesis and growth in mustard through changes in proline accumulation and ethylene formation under drought stress. S. Afr. J. Bot. 2015, 98, 84-94. [CrossRef]

82. Ghasemzadeh, A.; Jaafar, H. Interactive effect of salicylic acid on some physiological features and antioxidant enzymes activity in ginger (Zingiber officinale Roscoe). Molecules 2013, 18, 5965-5979. [CrossRef]

83. Fodor, J.; Gullner, G.; Adam, A.L.; Barna, B.; Komives, T.; Király, Z. Local and systemic responses of antioxidants to tobacco mosaic virus infection and to salicylic acid in tobacco (role in systemic acquired resistance). Plant Physiol. 1997, 114, 1443-1451. [CrossRef]

84. Király, Z.; Barna, B.; Kecskés, A.; Fodor, J. Down-regulation of antioxidative capacity in a transgenic tobacco which fails to develop acquired resistance to necrotization caused by TMV. Free Radic. Res. 2002, 36, 981-991. [CrossRef] 
85. Preciado-Rangel, P.; Reyes-Pérez, J.J.; Ramírez-Rodríguez, S.C.; Salas-Pérez, L.; Fortis-Hernández, M.; Murillo-Amador, B.; Troyo-Diéguez, E. Foliar Aspersion of Salicylic Acid Improves Phenolic and Flavonoid Compounds, and Also the Fruit Yield in Cucumber (Cucumis sativus L.). Plants 2019, 8, 44. [CrossRef]

86. Bhutia, D.D.; Zhimo, Y.; Kole, R.; Saha, J. Antifungal activity of plant extracts against Colletotrichum musae, the post-harvest anthracnose pathogen of banana cv. Martaman. Nutr. Food Sci. 2016, 46, 2-15. [CrossRef]

87. Bulgari, R.; Cocetta, G.; Trivellini, A.; Vernieri, P.; Ferrante, A. Biostimulants and crop responses: A review. Biol. Agric. Hortic. 2015, 31, 1-17. [CrossRef]

88. Massa, D.; Prisa, D.; Montoneri, E.; Battaglini, D.; Ginepro, M.; Negre, M.; Burchi, G. Application of municipal biowaste derived products in Hibiscus cultivation: Effect on leaf gaseous exchange activity, and plant biomass accumulation and quality. Sci. Horict. 2016, 205, 59-69. [CrossRef]

89. Yakhin, O.I.; Lubyanov, A.A.; Yakhin, I.A.; Brown, P.H. Biostimulants in plant science: A global perspective. Front. Plant Sci. 2017, 7, 2049. [CrossRef] [PubMed]

90. Gaige, A.R.; Ayella, A.; Shuai, B. Methyl jasmonate and ethylene induce partial resistance in Medicago truncatula against the charcoal rot pathogen Macrophomina phaseolina. Physiol. Mol. Plant Pathol. 2010, 74, 412-418. [CrossRef]

91. Kepczyńska, E.; Król, P. The phytohormone methyl jasmonate as an activator of induced resistance against the necrotroph Alternaria porri f. sp. solani in tomato plants. J. Plant Interact. 2012, 7, 307-315. [CrossRef]

92. Jiang, L.; Jin, P.; Wang, L.; Yu, X.; Wang, H.; Zheng, Y. Methyl jasmonate primes defense responses against Botrytis cinerea and reduces disease development in harvested table grapes. Sci. Hortic. 2015, 192, 218-223. [CrossRef]

93. Wang, K.; Liao, Y.; Kan, J.; Han, L.; Zheng, Y. Response of direct or priming defense against Botrytis cinerea to methyl jasmonate treatment at different concentrations in grape berries. Int. J. Food Microbiol. 2015, 194, 32-39. [CrossRef]

94. Ralhan, A.; Schöttle, S.; Thurow, C.; Iven, T.; Feussner, I.; Polle, A.; Gatz, C. The vascular pathogen Verticillium longisporum requires a jasmonic acid-independent COI function in roots to elicit disease symptoms in Arabidopsis shoots. Plant Physiol. 2012, 159, 1192-1203. [CrossRef]

95. Chen, Y.C.; Wong, C.L.; Muzzi, F.; Vlaardingerbroek, I.; Kidd, B.N.; Schenk, P.M. Root defense analysis against Fusarium oxysporum reveals new regulators to confer resistance. Sci. Rep. 2014, 4, 5584. [CrossRef]

96. Lyons, R.; Stiller, J.; Powell, J.; Rusu, A.; Manners, J.M.; Kazan, K. Fusarium oxysporum triggers tissue-specific transcriptional reprogramming in Arabidopsis thaliana. PLoS ONE 2015, 10, e0121902. [CrossRef] [PubMed]

97. Rahman, T.A.E.; Oirdi, M.E.; Gonzalez-Lamothe, R.; Bouarab, K. Necrotrophic pathogens use the salicylic acid signaling pathway to promote disease development in tomato. Mol. Plant Microbe Interact. 2012, 25, 1584-1593. [CrossRef] [PubMed]

98. Tiwari, S.; Pandey, D.; Gaur, M.; Kumar, A. Effect of Methyl Jasmonate on Disease Severity and Expression of Plant Defensin Gene during Alternaria brassicae Infection in Arabidopsis. Int. J. Curr. Microbiol. App. Sci. 2017, 6, 857-865. [CrossRef]

99. Leslie, J.F.; Summerell, B.A. The Fusarium Laboratory Manual, 1st ed.; Blackwell Publishing: Ames, IA, USA, 2006; p. 382.

100. Hainaut, P.; Remacle, T.; Decamps, C.; Lambert, R.; Sadok, W. Higher forage yields under temperate drought explained by lower transpiration rates under increasing evaporative demand. Eur. J. Agron. 2016, 72, 91-98. [CrossRef]

101. Park, D. Isolation of Fusarium oxysporum from soils. Trans. Br. Mycol. Soc. 1961, 44, 119-122. [CrossRef]

102. Makandar, R.; Nalam, V.J.; Lee, H.; Trick, H.N.; Dong, Y.; Shah, J. Salicylic acid regulates basal resistance to Fusarium head blight in wheat. Mol. Plant Microbe Interact. 2012, 25, 431-439. [CrossRef]

103. Thaler, J.S.; Owen, B.; Higgins, V.J. The role of the jasmonate response in plant susceptibility to diverse pathogens with a range of lifestyles. Plant Physiol. 2004, 135, 530-538. [CrossRef]

104. Moreno-Velandia, C. Interactions between Bacillus amyloliquefaciens Bs006, Fusarium oxysporun Map5 and Cape gooseberry (Physalis peruviana). Ph.D. Thesis, Universidad Nacional de Colombia, Bogotá, Colombia, 25 January 2018.

105. Townsend, G.R.; Heuberger, J.W. Methods for estimating losses caused by diseases in fungicide experiments. Plant Dis. Report. 1943, 27, 340-343.

106. Campbell, C.L.; Madden, L.V. Introduction to Plant Disease Epidemiology; Wiley-Interscience: New York, NY, USA, 1990; p. 532. 
107. Alves, D.P.; Tomaz, R.S.; Laurindo, B.S.; Laurindo, R.D.F.; Cruz, C.D.; Nick, C.; Silva, D.J.H.D. Artificial neural network for prediction of the area under the disease progress curve of tomato late blight. Sci. Agr. 2017, 74, 51-59. [CrossRef]

108. Xu, W.Z.; Deng, X.P.; Xu, B.C.; Gao, Z.J.; Ding, W.L. Photosynthetic activity and efficiency of Bothriochloa ischaemum and Lespedeza davurica in mixtures across growth periods under water stress. Acta Physiol. Plant 2014, 36, 1033-1044. [CrossRef]

109. Wellburn, A.R. The spectral determination of chlorophylls $a$ and $b$, as well as total carotenoids, using various solvents with spectrophotometers of different resolution. J. Plant Physiol. 1994, 144, 307-313. [CrossRef]

110. Sims, D.A.; Gamon, J.A. Relationships between leaf pigment content and spectral reflectance across a wide range of species, leaf structures and developmental stages. Remote Sens. Environ. 2002, 81, 337-354. [CrossRef]

111. Hodges, D.M.; DeLong, J.M.; Forney, C.F.; Prange, R.K. Improving the thiobarbituric acid-reactive-substances assay for estimating lipid peroxidation in plant tissues containing anthocyanin and other interfering compounds. Planta 1999, 207, 604-611. [CrossRef]

112. Bates, L.S.; Waldren, R.P.; Teare, I.D. Rapid determination of free proline for water-stress studies. Plant Soil 1973, 39, 205-207. [CrossRef]

(C) 2020 by the authors. Licensee MDPI, Basel, Switzerland. This article is an open access article distributed under the terms and conditions of the Creative Commons Attribution (CC BY) license (http://creativecommons.org/licenses/by/4.0/). 